\title{
EVALUATION OF A PROPOSED CONNECTOR WELL, NORTHEASTERN DESOTO COUNTY, FLORIDA
}

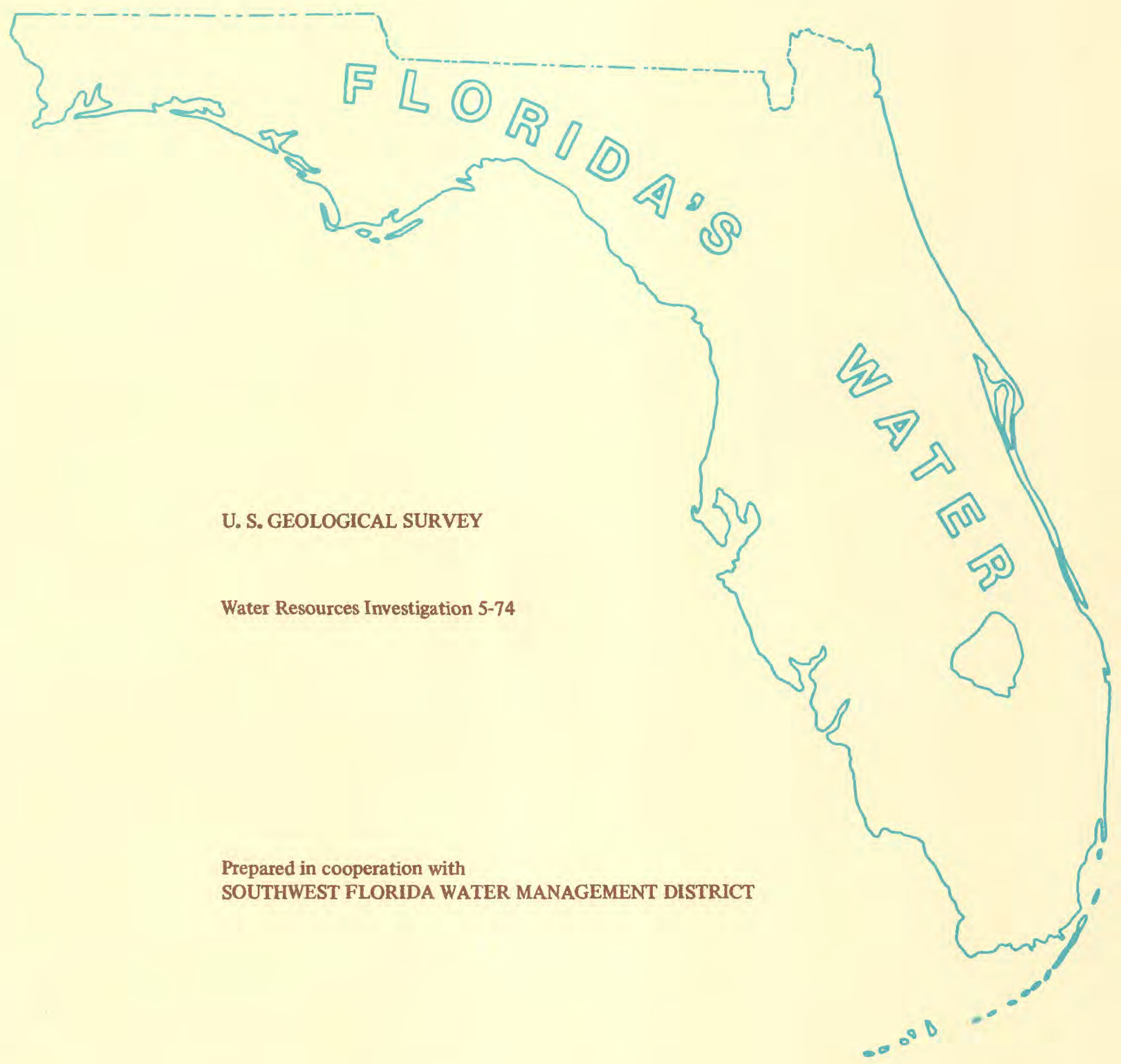

Prepared in cooperation with

SOUTHWEST FLORIDA WATER MANAGEMENT DISTRICT 


\begin{tabular}{|c|c|c|}
\hline $\begin{array}{l}\text { BIBLIOGRAPHIC DATA } \\
\text { SHEET }\end{array}$ & 1. Report No. & 3. Recipient's Accession No. \\
\hline \multirow{2}{*}{\multicolumn{2}{|c|}{$\begin{array}{l}\text { 4. Title and Subritle } \\
\text { Evaluation of a proposed connector we11, northeastern DeSoto } \\
\text { County, Florida }\end{array}$}} & $\begin{array}{l}\text { 5. Report Date } \\
\text { February } 1974\end{array}$ \\
\hline & & 6. \\
\hline \multicolumn{2}{|c|}{$\begin{array}{l}\text { 7. Author(s) } \\
\text { C. B. Hutchinson, William E. Wilson }\end{array}$} & $\begin{array}{l}\text { 8. Performing Organization Rept. } \\
\text { No. WRI } 5-74\end{array}$ \\
\hline \multirow{2}{*}{\multicolumn{2}{|c|}{$\begin{array}{l}\text { 9. Performing Organization Name and Address } \\
\text { U. S. Geological Survey } \\
325 \text { John Knox Road, Suite F-240 } \\
\text { Ta1lahassee, Florida } 32303\end{array}$}} & 10. Project/Task/Work Unir No. \\
\hline & & 11. Contract/Grant No. \\
\hline \multirow{2}{*}{\multicolumn{2}{|c|}{$\begin{array}{l}\text { 12. Sponsoring Organization Name and Address } \\
\text { U. S. Geological Survey } \\
325 \text { John Knox Road, Suite F-240 } \\
\text { Tallahassee, Florida } 32303\end{array}$}} & $\begin{array}{l}\text { 13. Type of Report \& Period } \\
\text { Covered } \\
\text { Initial }\end{array}$ \\
\hline & & 14. \\
\hline
\end{tabular}

15. Supplementary Notes

Presented at Southeastern Section, Geological Society of America, Atlanta, Georgia, Apri1 3-6, 1974.

16. Abstracts At a 24,000-acre citrus grove, a connector well is proposed as a resourcemanagement tool for capturing water normally lost through evapotranspiration and by excess runoff. Such a well would connect the surficial sand aquifer with the deep, highly transmissive 1imestone Floridan Aquifer. Because of natural head differences, water would move by gravity flow from the sand into the Floridan Aquifer, thus replenishing water withdrawn for irrigation from the Floridan Aquifer. A 70-acre marsh was selected as the test site based on analyses of hydraulic conductivity, porosity, and water quality. Recharge rate through the connector well under steady-state conditions is estimated at 160 gallons per minute. The proposed connector well is designed to have 10-inch screens opposite zones in the 45-foot thick sand aquifer, be cased for 400 feet opposite confining beds and a secondary limestone aquifer, and be open hole for about 250 feet in the Floridan Aquifer. A graded-sand filter pack placed around the screened sections of the we11 will increase its efficiency.

17. Key Words and Document Analysis. 17a. Descriptors Florida, *artificial recharge, recharge wells ground-water recharge, *water management (applied), water injection, water conservation evapotranspiration control, hydraulic conductivity, water storage, aquifer characteristics

17b. Identifiers/Open-Ended Terms *Connector wells, captured water, Floridan Aquifer

17c. COSATI Field/Group

18. Availability Statement

Release unlimited

\begin{tabular}{|l} 
19. Security Class (This \\
Report) \\
UNCLASSIFIED
\end{tabular}

THIS FORM MAY BE REPRODUCED
21. No, of Pages

22. Price


EVALUATION OF A PROPOSED CONNECTOR WELL, NORTHEASTERN DESOTO COUNTY, FLORIDA

By C. B. Hutchinson and William E. Wilson

U. S. GEOLOGICAL SURVEY

Water-Resources Investigations 5-74

Prepared in cooperation with

Southwest Florida Water Management District 
UNITED STATES DEPARTMENT OF THE INTERIOR

Rogers C. B. Morton, Secretary

GEOLOGICAL SURVEY

Vincent E. McKelvey, Director

For additional information write to:

U.S. Geological Survey

325 John Knox Rd., F-240

Tallahassee, Florida 32303 


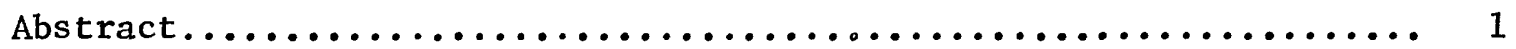

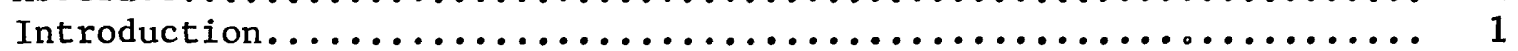

The connector-we11 concept............................. 3

Hydrogeologic setting................................. 4

Test site.......................................... 6

Site selection.................................. 6

Hydrogeologic conditions.......................... 8

Geology of unconsolidated deposits................. 8

Aquifer transmissivity......................... 8

Head relations............................... 8

Water quality................................. 13

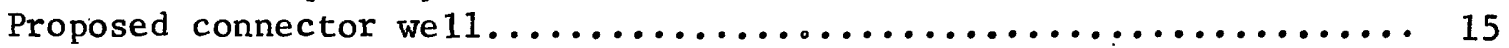

Recharge rate.................................... 15

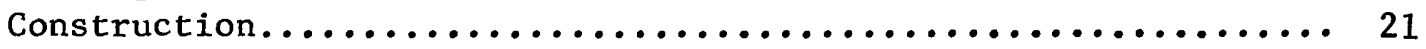

Summary and conclusions.............................. 26

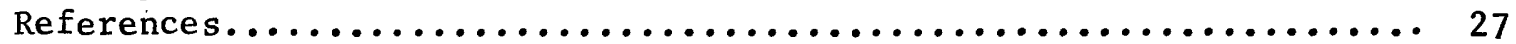

Appendixes 1. Lithologic logs of well and test-hole sites........ 28

2. Equations for computing recharge rate of a single connector well........................ 40 
1. Map showing location of the citrus-grove study area, DeSoto

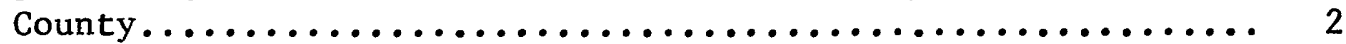

2. Map of citrus grove showing locations of test-hole sites and wells, and details of connector-well test site.......... 7

3. Geologic section $A-A^{\prime}$ showing lithology of the sand aquifer and the observation-we 11 network at the connector-we 11 test site.................................... 9

4. Graph showing recharge rate versus time after recharge started through a connector wel1......................... 16

5. Diagrammatic section and plan view showing relation between maximum capture rate and cone of depression around a single

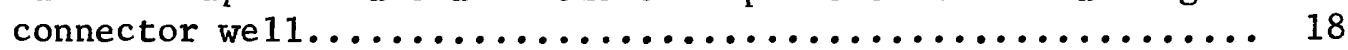

6. Grain-size distribution curves for upper and lower sand units and corresponding curves for filter-pack material........ 22

7. Diagram showing design of the test connector we 11 and filter

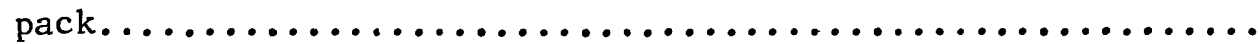




\section{TABLES}

Table

Page

1. Hydrogeologic units at the project citrus grove, northeastern

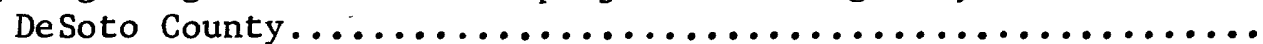

2. Physical characteristics of split-spoon samples from we $114 \ldots \ldots 10$

3. Transmissivity of the sand aquifer..................... 12

4. Quality of ground water............................... 14

5. Estimated recharge rate of a test connector we $11 \ldots \ldots \ldots \ldots . \ldots 19$

6. Data for design of test connector-we11 screen and filter pack.. 23 
FACTORS FOR CONVERTING ENGLISH UNITS TO INTERNATIONAL

SYSTEM (SI) UNITS

\begin{tabular}{|c|c|c|}
\hline Multiply English units & By & To obtain SI units \\
\hline \multicolumn{3}{|c|}{ Length } \\
\hline $\begin{array}{l}\text { inches (in.) } \\
\text { feet (ft) } \\
\text { miles (mi) }\end{array}$ & $\begin{array}{l}25.4 \\
2.54 \\
.025 \\
.305 \\
1.6\end{array}$ & $\begin{array}{l}\text { millimeters }(\mathrm{mm}) \\
\text { centimeters }(\mathrm{cm}) \\
\text { meters }(\mathrm{m}) \\
\text { meters }(\mathrm{m}) \\
\text { kilometers }(\mathrm{km})\end{array}$ \\
\hline \multicolumn{3}{|c|}{ Area } \\
\hline $\begin{array}{l}\text { acres } \\
\text { square miles }\left(\mathrm{mi}^{2}\right)\end{array}$ & $\begin{array}{l}.405 \\
4.05 \times 10^{-} \\
2.59\end{array}$ & $\begin{array}{l}\text { hectares (ha) } \\
\text { square kilometers }\left(\mathrm{km}^{2}\right. \\
\text { square kilometers }\left(\mathrm{km}^{2}\right.\end{array}$ \\
\hline \multicolumn{3}{|c|}{ Volume } \\
\hline gallons (gal) & $\begin{array}{l}3.79 \\
3.79\end{array}$ & $\begin{array}{l}\text { liters }(1) \\
\text { cubic meters }\left(\mathrm{m}^{3}\right)\end{array}$ \\
\hline \multicolumn{3}{|c|}{ F1ow } \\
\hline $\begin{array}{l}\text { gallons per minute (gpm) } \\
\text { million gallons per day (mgd) }\end{array}$ & $\begin{array}{l}.063 \\
.044\end{array}$ & $\begin{array}{l}\text { liters per second }(1 / \mathrm{s}) \\
\text { cubic meters }{ }_{3} \text { per } \\
\text { second }\left(\mathrm{m}^{3} / \mathrm{s}\right)\end{array}$ \\
\hline \multicolumn{3}{|c|}{ Transmissivity } \\
\hline square feet per day ( $f t^{2} /$ day) & 0.093 & $\begin{array}{l}\text { square meters per day } \\
\left(\mathrm{m}^{2} / \text { day }\right)\end{array}$ \\
\hline \multicolumn{3}{|c|}{ Hydraulic conductivity } \\
\hline feet per day (ft/day) & 0.305 & meters per day (m/day) \\
\hline \multicolumn{3}{|c|}{ Specific capacity } \\
\hline $\begin{array}{l}\text { gallons per minute per foot } \\
(\mathrm{gpm} / \mathrm{ft})\end{array}$ & 0.207 & $\begin{array}{l}\text { 1iters per second per } \\
\text { meter }(1 / \mathrm{s} / \mathrm{m})\end{array}$ \\
\hline
\end{tabular}




\section{EVALUATION OF A PROPOSED CONNECTOR WELL, NORTHEASTERN \\ DESOTO COUNTY, FLORIDA}

By C. B. Hutchinson and William E. Wilson

\section{ABSTRACT}

A connector well is proposed as a resource-management tool for capturing water normally lost through evapotransipration and by runoff in a 24,000-acre $(9,700$-hectare) citrus grove in northeastern DeSoto County. The well would connect the surficial sand aquifer with the deep, highly transmissive Floridan 1imestone aquifer. Because of natural head differences, water would move by gravity flow from the upper into the lower aquifer. An investigation was conducted to determine the hydrologic and geologic suitability of the area for connector wells, and to design a test connector we11 and estimate its probable yield.

A 70-acre (28-hectare) marsh was selected for a test site. The sand aquifer, about 45 feet (14 meters) thick, consists of an upper fine sand unit and a lower medium-coarse sand unit, separated by a clay bed 5 feet (1.5 meters) thick. Transmissivity of this aquifer is about 1,750 square feet (163 square meters) per day. Under natural conditions, the water table is about 40 feet ( 12 meters) above the potentiometric surface of the Floridan Aquifer. Water in the sand aquifer is of suitable quality for recharging the Floridan Aquifer.

Estimated recharge rate of the proposed connector well is about 160 gallons per minute (10.7 liters per second) under steady-state conditions. Recharge rates can probably be increased by installing subsurface drain tiles, flooding the marsh surface, and perforating the clay bed in the sand aquifer.

The proposed connector wel1 is designed to have two sand-packed screens, 10 inches (25 centimeters) in diameter, one in the upper and the other in the lower unit of the sand aquifer; about 400 feet (120 meters) of 6-inch (15-centimeter) casing through confining beds and a secondary limestone aquifer; and about 250 feet (76 meters) of open hole in the Floridan Aquifer.

\section{INTRODUCTION}

Florida's largest citrus grove has been established in northeastern DeSoto County (fig. 1). About 24,000 acres $\left(37.5 \mathrm{mi}^{2}\right.$ ) or 9,700 hectares have been planted in citrus. The principal source of water for irrigation is the Floridan Aquifer, a highly transmissive artesian limestone aquifer which occurs from about 500 to 1,500 feet (i50 to $450 \mathrm{~m}$ ) below 


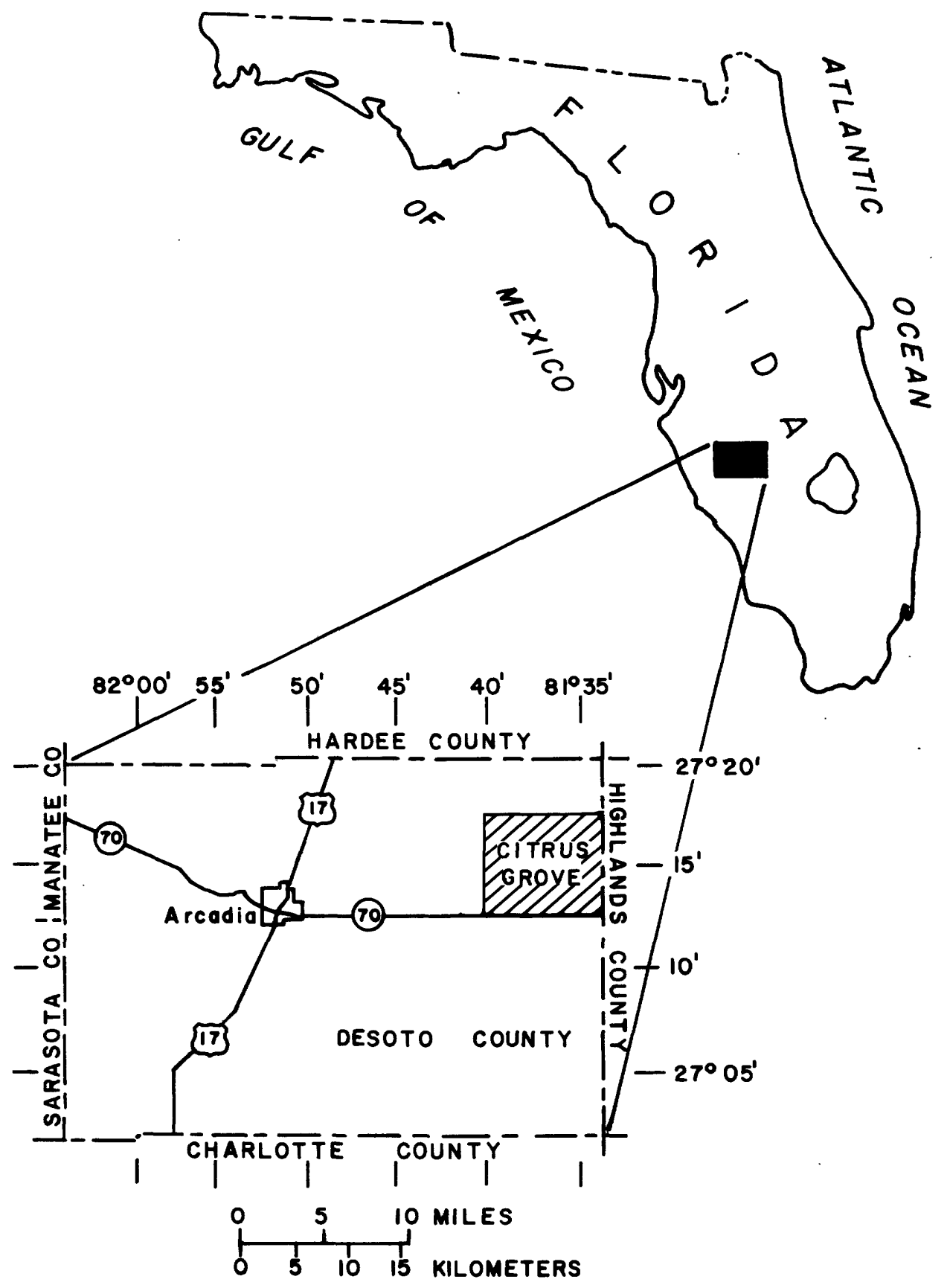

Figure 1. Location of the citrus grove study area, DeSoto County. 
the land surface. As a resource-management tool, it may be feasible to use connector we1ls to recharge this aquifer with ground water from a shallow sand aquifer.

This report presents the results of a 1-year study undertaken by the U. S. Geological Survey in cooperation with the Southwest Florida Water Management District. The objectives of the investigation were to: (1) determine the hydrologic and geologic suitability of the area for installing connector wells; (2) make a preliminary estimate of the amount and quality of water available for recharge; and (3) suggest a possible construction for a test connector we11.

The authors gratefully acknowledge the cooperation and assistance of personne 1 of American Agronomics Corporation and American International Food Corporation. Personnel at Tropical River Groves generously provided time and equipment to expedite the investigation. Herman Cail, Grove Superintendent, and Kenneth A. Harris, Consulting Engineer, offered encouragement and support for the investigation through their many helpful comments and suggestions.

\section{THE CONNECTOR-WELL CONCEPT}

Connector we11s have been considered to be a potential resourcemanagement tool for central Florida for many years, but not until the late 1960 's were detailed field investigations undertaken to determine the hydrologic and geologic feasibility of installing such we11s. Test connector wells have been installed by the U. S. Geological Survey near Orlando and Tampa, and industrial applications are being tested in the phosphate district in Polk County.

A connector we 11 is so named because it connects two aquifers that, under natural conditions, are hydraulically separated by a confining bed. In northeastern DeSoto County, as elsewhere in central Florida, one feasible combination would be to screen opposite the sand aquifer, penetrate and case through confining beds, and drill open hole in the Floridan Aquifer. Because the water table is higher than the potentiometric surface of the artesian aquifer, ground water would move by gravity flow from the upper to the deeper aquifer through the connector well. Thus, connector we1ls differ from injection wells and drainage we11s that have been used in Florida to dispose of surface water and waste water directly from the land surface into the ground. In contrast to the se wells, connector wells recharge water that has moved through the natural filter of unconsolidated deposits.

Water for a connector we11 is derived initially from aquifer storage and ultimately from a reduction in previous aquifer discharge, or an increase in recharge to the aquifer, or a combination of these. These changes in recharge-discharge are termed capture (Lohman and others, 1972, p. 3). Captured water for a connector well is primarily water that would have otherwise run off or evapotranspired. 
As a result of recharge by connector wells, lowering of the artesian potentiometric surface caused by pumping is reduced, and water normally lost to evapotranspiration or runoff is continuously captured and returned to storage for future withdrawal. In addition, the successful operation of a connector well offers the possibility of converting water-logged marshes into tillable land. From a drainage standpoint, lowering the water table below the depth of citrus root zones would make the land more suitable for citrus growth. Other considerations, however, may make this management alternative impractical or undesirable. Among them are the extent of land preparation required, the effects on surface runoff, the desirability of retaining flooding capabilities, and the ecological desirability of retaining marshland.

\section{HYDROGEOLOGIC SETTING}

The area of investigation lies in the nearly flat prairieland of the DeSoto Plain, in the Gulf Coastal Lowlands physiographic unit of Puri and Vernon (1964). Land-surface altitudes range from 75 to $95 \mathrm{ft}(23$ to $29 \mathrm{~m})$ above mean sea level. Under natural conditions the land is poorly drained and the water table is at or near land surface during most of the year. The numerous shallow depressions that dot the landscape form marshes that intermittently contain water. At the grove site, an extensive system of ditches and network of control structures have been installed to control both runoff and the level of the shallow water table.

The hydrogeologic units underlying the grove area include the sand aquifer, a secondary artesian aquifer, the Floridan Aquifer, and intervening confining beds (table 1 ). The deposits of the sand aquifer are variable in texture, but are predominantly fine grained. At the grove, the depth to the water table in the aquifer is generally maintained within a few feet of land surface by controlling water levels in the ditches. This aquifer is not tapped by we 11 s at the grove.

The secondary and Floridan artesian aquifers, principal1y limestone and dolomite of Eocene to Miocene age, are the sources of ground water for irrigation at the grove. The highly transmissive Floridan Aquifer, which underlies all of Florida, is about $1,000 \mathrm{ft}(300 \mathrm{~m})$ thick here and comprises the Avon Park Limestone, Ocala Limestone, and Suwannee Limestone.

A confining bed of about $150 \mathrm{ft}(45 \mathrm{~m})$ of interbedded sand, clay, and marl within the Tampa Limestone separates the Floridan Aquifer from the overlying secondary aquifer. The secondary aquifer consists of about 150 ft $(45 \mathrm{~m})$ of permeable limestone within the Hawthorn Formation and is confined above by 100 to $150 \mathrm{ft}(30$ to $45 \mathrm{~m})$ of sandy clay and mar 1 .

Irrigation wells at the grove are drilled open hole through the secondary and Floridan aquifers and are cased through the sand aquifer and the confining beds. By 1972,37 wells had been drilled, one per squaremile section. We11 depth averages about $1,340 \mathrm{ft}(400 \mathrm{~m})$ and the yield averages about $1,800 \mathrm{gpm}$ (gallons per minute), or $1141 / \mathrm{s}$ (1iters per second). Field specific capacities computed for 15 wells range from 13 to $121 \mathrm{gpm} / \mathrm{ft}$ $(2.7$ to $251 / \mathrm{s} / \mathrm{m})$ and average $62 \mathrm{gpm} / \mathrm{ft}(131 / \mathrm{s} / \mathrm{m})$. 


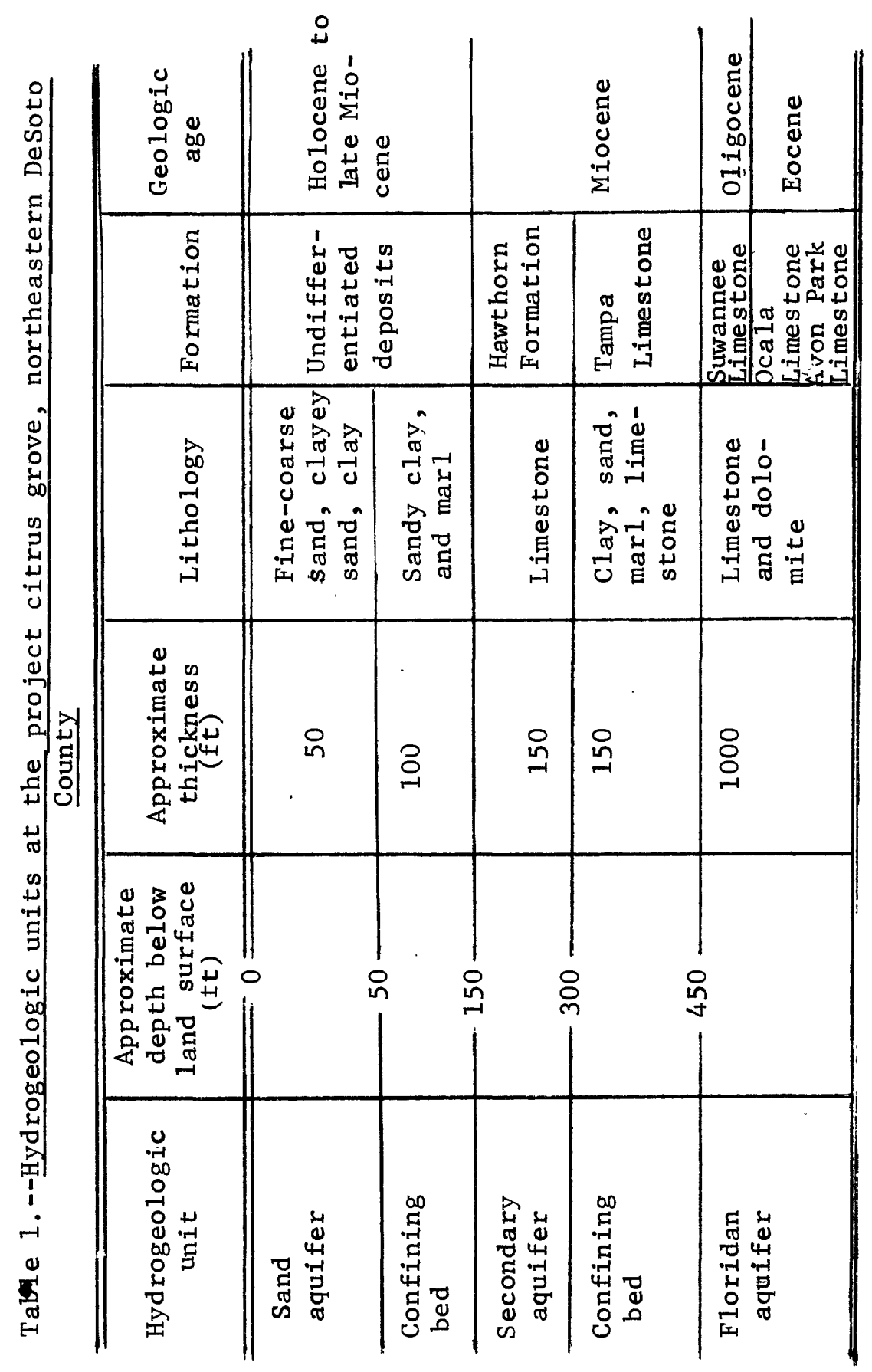


Irrigation at the grove is seasonal, with heaviest pumping during the dry spring months, and little or no pumping during the rainy summer months. During 1971 and 1972 , pumpage averaged about $12.5 \mathrm{mgd}$ (million gallons per day), or $0.55 \mathrm{~m}^{3} 6 \mathrm{~s}$ (cubic meters per second), withdrawal rates were as high as $46 \mathrm{mgd}(2.0 \mathrm{~m} / \mathrm{s})$ during the spring. Wells discharge directly into ditches used to control the level of the water table beneath planted areas.

Under non-pumping conditions, the integrated potentiometric surface, as measured in irrigation wells open to both the secondary and Floridan aquifers, has a very gentle gradient and is about 35 to $40 \mathrm{ft}$ (10.7 to 12.2 m) below land surface. Probably little head difference exists between the two artesian aquifers under non-pumping conditions. During the irrigation season, the integrated potentiometric surface declines to more than $50 \mathrm{ft}$ $(15.2 \mathrm{~m})$ below land surface. Thus, throughout the year, a head difference of at least $40 \mathrm{ft}(12.2 \mathrm{~m})$ exists between the sand aquifer and the artesian aquifers.

The combined transmissivity of the secondary and Floridan Aquifers is about $270,000 \mathrm{ft}^{2} /$ day ( $2 \mathrm{mi11i}$ on $\mathrm{gpd} / \mathrm{ft}$ ), or $25,000 \mathrm{~m}^{2} /$ day (Wilson, 1972 , p. 301). The hydraulic characteristics of these two aquifers have not been determined separately, but the contribution to water pumped by irrigation we 11s at the grove is much greater from the Floridan Aquifer than from the secondary aquifer. The proposed connector well will recharge only the Floridan Aquifer.

\section{TEST STTE}

\section{Site Selection}

The grove contains numerous marshy, shallow depressions that are unsuitable for citrus growth. These depressions, which individually may cover as much as 100 acres ( $40 \mathrm{ha})$, act as natural collecting basins for surface runoff, and during the wet period (June-September), water may be $3 \mathrm{ft}(1 \mathrm{~m})$ deep in them. The depressions were deened feasible sites for artificial-recharge experiments. A power auger was used to test drill six of the marsh areas to determine the most suitable site for a test connector we11. Selection of drilling sites was based upon two criteria: (1) size of the marsh, the largest ones being most acceptable, and (2) evenness of areal distribution so that a11 quadrants of the grove were tested. Splitspoon samples were taken at $5 \mathrm{ft}(1.5 \mathrm{~m})$ intervals to depths of about 60 ft $(18 \mathrm{~m})$ ensuring good penetration of the upper confining bed. Locations of test-hole sites are shown on figure 2, and logs of all test holes are given in appendix 1 .

At all marsh sites, the samples indicated about $50 \mathrm{ft}(15 \mathrm{~m})$ of sand and clayey sand. At one site in the northwestern part of the grove, a particularly we11-sorted $15-\mathrm{ft}$ (5-m) bed of medium-coarse sand was found. This marsh, covering about 70 acres ( 28 ha), was selected as the test site (fig. 2) for construction of a connector well. 


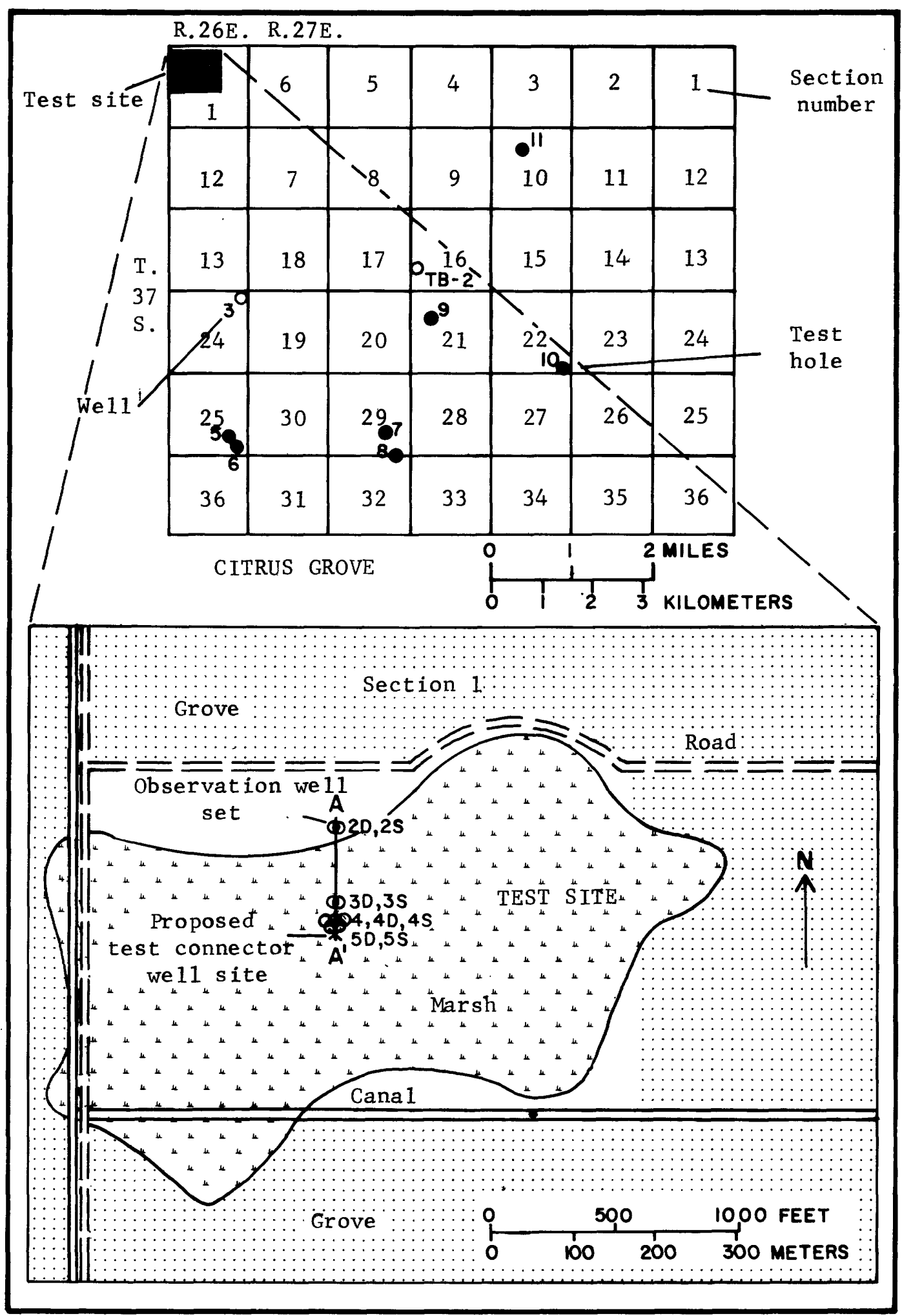

Figure 2. Map of citrus grove showing locations of test-hole sites and wells, and details of connector-well test site. 


\section{Hydrogeologic Conditions}

\section{Geology of Unconsolidated Deposits}

The unconsolidated deposits of the sand aquifer are mostly post-Miocene in age. Figure 3, a north-south cross section through a line of observation we11s, shows 1ithology of the aquifer and sampling points at the test site. The section consists of an upper unit of we 11 -sorted fine to medium sand that becomes phosphatic and clayey as it grades to a stiff clay at a depth of about $25 \mathrm{ft}(7.6 \mathrm{~m})$. This layer of stiff, greenish-gray clay was found at all well sites at a depth of 25 to $30 \mathrm{ft}(7.6$ to $9.2 \mathrm{~m})$. The contact between the clay and the underlying lower sand unit is sharp. Below the clay lies a poorly sorted, medium-to-coarse, slightly clayey sand which becomes we 11 sorted from about 35 to $50 \mathrm{ft}(11$ to $15 \mathrm{~m})$.

Some physical characteristics of the unconsolidated deposits at the test site are summarized in table 2. The results are based on analyses of split-spoon samples. Median grain size and two sorting parameters, uniformity coefficient and standard deviation sorting factor, were determined from curves of grain-size distribution, based on sieve analyses. Sample descriptions are based on a system of Shepard, as described by Pettijohn (1957, p. 24), using the Wentworth grain-size classification.

\section{Aquifer Transmissivity}

Transmişivity of the sand aquifer is probably 1,500 to $2,000 \mathrm{ft}^{2} / \mathrm{day}$ (140 to $185 \mathrm{~m}^{2} / \mathrm{day}$ ), as determined from the sum of the products of average horizontal hydraulic conductivity and thickness of individual lithologic units (table 3 ). Hydraulic conductivities are based on grain size and sorting and are probably conservatively low (Masch and Denny, 1966). Hydraulic conductivity was not determined for beds of the sand aquifer that are poorly sorted (high uniformity coefficient) or have a bimodal grainsize distribution. However, hydraulic conductivities of these beds are low and do not significantly contribute to the 5 ransmissivify of the total section. An average transmissivity of $1,750 \mathrm{ft}^{2} / \mathrm{day}(163 \mathrm{~m} / \mathrm{day})$ was used in the analyses of recharge rates.

\section{Head Relations}

The geologic section of figure 3 shows that the water table is approximately at land surface at the marsh. This position is based on five measurements made from May to September 1972 in each of two observation we $11 \mathrm{~s} 30 \mathrm{ft}(9 \mathrm{~m})$ from the proposed test connector-we 11 site. One we 11 (4S) is developed opposite the upper fine sand unit, and the other (4D) is opposite the lower medium-coarse sand unit. The altitude of land surface at both we $11 \mathrm{~s}$ is about $88 \mathrm{ft}(27 \mathrm{~m})$ above mean sea leve1: The May and September water-leve 1 depths in the two we11s, in feet above (+) or below (-) land surface, were as follows: 


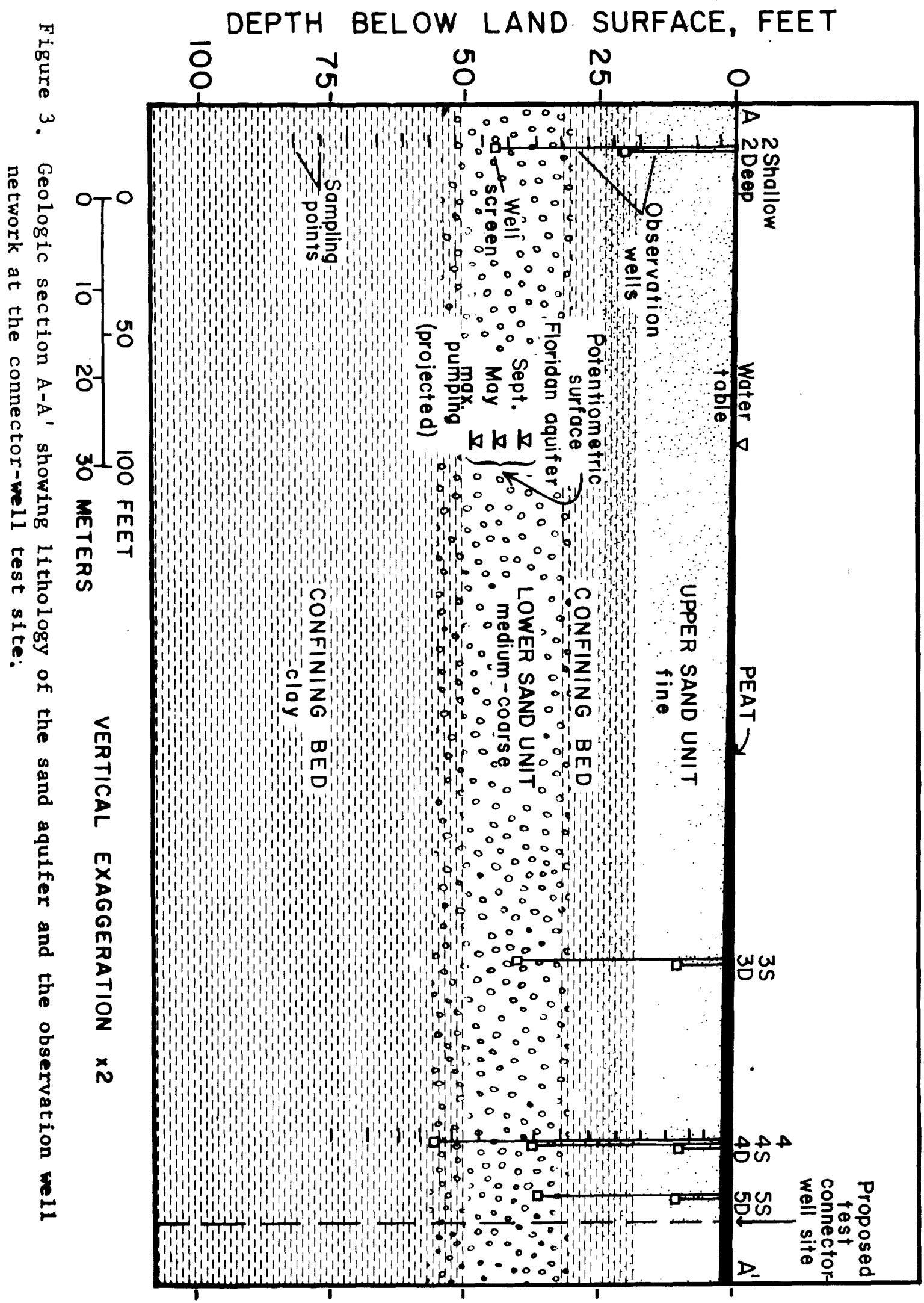


Table 2--Physical characteristics of split-spoon samples from we 114

\begin{tabular}{|c|c|c|c|c|c|}
\hline \multirow{2}{*}{$\begin{array}{l}\text { Depth } \\
\text { below land } \\
\text { surface } \\
\text { (ft) }\end{array}$} & \multirow{2}{*}{ Description ${ }^{1}$} & \multirow{2}{*}{$\underset{\underset{(\mathrm{mm})}{\operatorname{Median}}}{\operatorname{grain} \operatorname{size}} \mathrm{D}_{50}$} & \multicolumn{3}{|c|}{$\begin{array}{l}\text { Grain-size distribution } \\
\text { (percent) }\end{array}$} \\
\hline & & & Clay & Silt & Sand \\
\hline 0.5 & Peat & - & - & - & - \\
\hline 5 & Fine sand & 0.17 & 0 & 0 & 100 \\
\hline 8 & Fine sand & .15 & $2.0 \pm$ & $3.3 \pm$ & 94.7 \\
\hline 12 & Fine sand & .19 & 0 & 0 & 100 \\
\hline 17 & Medium sand & .37 & 14.4 & 0.5 & 85.1 \\
\hline 22 & Medium sand & .50 & $5.0 \pm$ & $1.9 \pm$ & 93.1 \\
\hline 27 & Silty clay & .004 & 42.9 & 41.5 & 15.6 \\
\hline 32 & Coarse sand & .55 & 10.4 & 1.8 & 87.8 \\
\hline 37 & Coarse sand & .65 & 0 & 0 & 100 \\
\hline 42 & $(7)$ & - & - & - & - \\
\hline 47 & Medium sand & .34 & 0 & 0 & 100 \\
\hline 52 & Fine sand & .22 & 5.7 & 3.2 & 91.1 \\
\hline 58 & Fine sand & .25 & 0 & 0 & 100 \\
\hline 62 & Fine sand & .19 & 11.0 & 0 & 89.0 \\
\hline 68 & Fine sand & .20 & 0 & 0 & 100 \\
\hline 74 & Fine sand & .17 & 11.5 & 7.1 & 81.4 \\
\hline
\end{tabular}

1 Determined from ternary diagram of Shepard (as described in Pettijohn, 1957), using median grain size as a modifier.

$2 \mathrm{D}_{50}$ is the grain diameter corresponding to the 50 percent-finer value on the particle-size curve.

3 Determined by averaging the slope of the particle-size curve between $\mathrm{D}_{10}$ and $\mathrm{D}_{60}$ diameters.

4 Calculated from the equation: $\left[\left(\phi_{84}-\phi_{16}\right) / 4+\left(\phi_{95}-\phi_{5}\right) / 6.6\right]=\sigma_{1}$
(Masch and Denny, 1966).

5 Derived from family of $\sigma_{1}$ curves plotted on graph of $D_{5}$ vs. K (Masch and Denny, 1966). Not determined for samples with either a bimodal particle-size distribution or a $\mathrm{C}_{\mathrm{u}}$ greater than 5.0 .

6 Determined from laboratory tèsts of undisturbed samples.

7 Similar to the sample taken at 37 feet. 
Table 2.--Physical characteristics of split-spoon samples from wel1 4 (cont)

\begin{tabular}{|c|c|c|c|c|c|}
\hline \multirow{2}{*}{$\begin{array}{c}\text { Depth } \\
\text { below } \\
\text { land } \\
\text { surface } \\
\text { (ft) }\end{array}$} & \multicolumn{2}{|c|}{ Sorting } & \multirow{2}{*}{$\begin{array}{l}\text { Total } \\
\text { porosity } \\
\text { (percent) }\end{array}$} & \multicolumn{2}{|c|}{$\begin{array}{c}\text { Hydraulic conductivity, } \\
\mathrm{K}(\mathrm{ft} / \mathrm{day})\end{array}$} \\
\hline & $\begin{array}{l}\text { Uniformity } \\
\text { coefficient, } \\
\mathrm{C}_{\mathrm{u}}\end{array}$ & $\begin{array}{l}\text { Standard } \\
\text { deviatjon } \\
\text { factor }, \quad 1\end{array}$ & & Horizónta ${ }^{5}$ & Vertica ${ }^{6}$ \\
\hline $\begin{array}{l}0.5 \\
5 \\
8 \\
12 \\
17 \\
22 \\
27 \\
32 \\
37 \\
42 \\
47 \\
52 \\
58 \\
62 \\
68 \\
74 \\
\end{array}$ & $\begin{aligned} &- \\
& 2.56 \\
& 2.57 \\
& 2.53 \\
&>5 \\
& 4.21 \\
&> 5 \\
&>5 \\
& \\
& 2.54 \\
&- \\
& 2.53 \\
& 2.93 \\
& 2.07 \\
&>5 \\
& 1.59 \\
&>5 \\
&\end{aligned}$ & $\begin{array}{l}- \\
0.93 \\
1.11 \\
.97 \\
- \\
- \\
- \\
.68 \\
-.88 \\
- \\
- \\
- \\
- \\
\end{array}$ & $\begin{array}{l}- \\
- \\
33.3 \\
- \\
36.7 \\
35.2 \\
53.4 \\
41.2 \\
32.3 \\
- \\
38.6 \\
40.2 \\
- \\
45.2 \\
- \\
47.5 \\
\end{array}$ & $\begin{array}{l}- \\
20.1 \\
16.7 \\
21.4 \\
- \\
- \\
- \\
- \\
120.3 \\
- \\
40.1 \\
- \\
- \\
- \\
- \\
- \\
\end{array}$ & $\begin{array}{l}0.07 \\
- \\
3.02 \\
- \\
.01 \\
.28 \\
1.1 \times 10^{-5} \\
.05 \\
15.1 \\
-\quad \\
.36 \\
.25 \\
-.03 \\
-.03 \\
\end{array}$ \\
\hline
\end{tabular}


Table 3.--Transmissivity of the sand aquifer

\begin{tabular}{|c|c|c|c|c|}
\hline $\begin{array}{l}\text { Depth } \\
\text { below } \\
\text { land } \\
\text { surface } \\
\text { (ft) }\end{array}$ & $\begin{array}{c}\text { Lithologic } \\
\text { unit }\end{array}$ & $\begin{array}{c}\text { Thick- } \\
\text { ness } \\
(\mathrm{ft})\end{array}$ & $\begin{array}{l}\text { Average } \\
\text { horizontal } \\
\text { hydraulic } \\
\text { conductivity } \\
\text { (ft/day) } 1\end{array}$ & $\begin{array}{l}\text { Trans- } \\
\text { missivity } \\
\left(\mathrm{ft}^{2} / \text { day }\right)\end{array}$ \\
\hline $\begin{array}{r}0-17 \\
17-25 \\
25-30 \\
30-35 \\
35-45 \\
45-50 \\
50\end{array}$ & $\begin{array}{l}\text { Fine sand } \\
\text { Clayey sand } \\
\text { Clay } \\
\text { Clayey sand } \\
\text { Coarse sand } \\
\text { Medium sand } \\
\text { Clayey sand }\end{array}$ & $\begin{array}{r}17 \\
8 \\
5 \\
5 \\
10 \\
5 \\
-\end{array}$ & $\begin{array}{l}19.4 \\
(2) \\
(2) \\
(2) \\
120.3 \\
40.1 . \\
(2)\end{array}$ & $\begin{array}{c}330 \\
- \\
- \\
- \\
1,200 \\
200 \\
- \\
\end{array}$ \\
\hline
\end{tabular}

1

See table 2 .

2 No estimate of hydraulic conductivity made because of poor sorting and bimodal grain-size distribution. 
The difference in head between the two sand units and the difference in range of fluctuation indicate that the intervening $5-\mathrm{ft}(1.5-\mathrm{m})$ clay bed effectively separates the units hydraulically. Depth of the contact between the clay bed and the lower sand unit is about $30 \mathrm{ft}(9 \mathrm{~m})$. The water leve 1 in we $114 \mathrm{D}$ stands above this contact, indicating that water in this unit is confined. The water level in well $4 \mathrm{~S}$ was above land surface in September and coincided closely with the level of standing water in the marsh, indicating unconfined conditions in the upper sand unit.

The approximate seasonal positions of the integrated potentiometric surface of the secondary and Floridan aquifers are shown on figure 3. Seasonal positions are based on static water-level measurements in an observation we11 about $2,000 \mathrm{ft}(610 \mathrm{~m})$ northwest of the test site. When the $\quad 42 \mathrm{mi}^{2}\left(109 \mathrm{~km}^{2}\right)$ of grove are fully developed, an additional seasonal decline of about $5 \mathrm{ft}(1.5 \mathrm{~m})$ is projected, based on anticipated pumping rates and patterns (Wilson, 1972, p. 304). Thus, the lowest depth expected would be about $50 \mathrm{ft}(15 \mathrm{~m})$ below 1 and surface.

The relative positions of the water levels indicate 40 to $50 \mathrm{ft}$ (12 to $15 \mathrm{~m}$ ) of head difference available to move shallow ground water through the connector-we11 screens, to the deep aquifer. Because the transmissivity of the artesian limestone aquifer is very much greater than that of the sand aquifer $(>100 \mathrm{x})$, the water level in the functioning connector well will ultimately approximate the position of the potentiometric surface.

\section{Water Quality}

Ground water in the sand aquifer has a lower dissolved-solids concentration than water in the secondary and Floridan aquifers (table 4). The water from the Floridan Aquifer is a calcium magnesium sulfate type. Water in the lower sand unit has almost the same relative composition as that in the secondary aquifer, but that in the secondary has a higher dissolvedsolids concentration. Water pumped from the grove irrigation wells is suitable for citrus production but it is characteristically very hard and high in concentration of sulfate and dissolved solids.

The relatively high iron concentration of $8.6 \mathrm{mg} / 1$ (milligrams per liter) in the upper sand unit (table 4) may result from reduction of organic materials in the overlying peat layer. Iron may be troublesome from the standpoint of the efficiency of operation of a connector well because as recharge water passes through the connector-well screens, it may become aerated, producing an oxidizing condition favorable for the deposition of iron oxide. The deposition may eventually clog the screens, but the rate of clogging is unknown. 
Table 4.--Quality of ground water

\begin{tabular}{|c|c|c|c|c|}
\hline \multirow[b]{2}{*}{$\begin{array}{l}\text { Quality parameter } \\
\text { (Al1 concentrations } \\
\text { in milligrams per } \\
\text { liter, except as } \\
\text { noted) }\end{array}$} & \multicolumn{2}{|c|}{ Sand aquifer } & \multirow[b]{2}{*}{$\begin{array}{l}\text { Secondary } \\
\text { aquifer } \\
\text { (Well TB-2) }\end{array}$} & \multirow[b]{2}{*}{$\begin{array}{l}\text { Floridan } \\
\text { Aquifer } \\
\text { (We11 } 3 \text { ) }\end{array}$} \\
\hline & $\begin{array}{l}\text { Upper } \\
\text { sand unit } \\
\text { (We11 } 2 \mathrm{~S})\end{array}$ & $\begin{array}{l}\text { Lower } \\
\text { sand unit } \\
\text { (Well } \quad \text { 2D) }\end{array}$ & & \\
\hline Color (Pt-Co units) & 45 & 40 & 0 & 15 \\
\hline Silica $\left(\mathrm{SiO}_{2}\right)$ & 15 & 25 & 38 & 21 \\
\hline Calcium (Caf & 24 & 13 & 32 & 100 \\
\hline Magnesium (Mg) & 5.6 & 4.3 & 26 & 50 \\
\hline Strontium (Sr) $(\mu \mathrm{g} / 1)$ & .12 & .17 & 5.6 & 21 \\
\hline Sodium (Na) & 12 & 22 & 78 & 18 \\
\hline Potassium (K) & .9 & 1.6 & 6.3 & 2.9 \\
\hline $\mathrm{pH}$ & 6.3 & 6 & 8.3 & 7.1 \\
\hline Bicarbonate $\left(\mathrm{HCO}_{3}\right)$ & 110 & 60 & 210 & 136 \\
\hline Sulfate $\left(\mathrm{SO}_{4}\right)$ & .8 & 0 & 81 & 360 \\
\hline Chloride (C1) & 12 & 31 & 81 & 25 \\
\hline Fluoride (F) & .7 & .6 & 2.6 & 1.1 \\
\hline Alkalinity as $\mathrm{CaCO}_{3}$ & 90 & 49 & 72 & 112 \\
\hline $\mathrm{Ca}-\mathrm{Mg}$ hard. as $\mathrm{CaCO}_{3}^{2}$ & 83 & 50 & 194 & 480 \\
\hline Non. Carb . hard.as $\mathrm{CaCO}_{3}$ & 0 & 1 & 22 & 370 \\
\hline Diss, solids residue & 143 & 157 & & 728 \\
\hline Diss. solids-sum & 125 & 128 & 454 & $\begin{array}{l}666 \\
970\end{array}$ \\
\hline $\begin{array}{l}\text { Specific conductance } \\
\left(\mu \text { mhos at } 25^{\circ} \mathrm{C}\right)\end{array}$ & 230 & 220 & 740 & $9 / 0$ \\
\hline Aluminum (A1) & 0 & .1 & - & 0 \\
\hline Arsenic (As) & 0 & 0 & - & 0 \\
\hline Boron (B) & .24 & .09 & - & .04 \\
\hline Cadmium (Cd) & 0 & 0 & - & 0 \\
\hline Copper (Cu) & 0 & 0 & - & 0 \\
\hline Iron (Fe) & 8.6 & 1.2 & - & .9 \\
\hline Lead $(\mathrm{Pb})$ & 0 & .001 & - & .002 \\
\hline Zinc $(\mathrm{Zn})$ & .74 & .31 & - & .03 \\
\hline Org. Carbon (filt.) & 24 & 16 & - & - \\
\hline Inorg. Carbon (filt.) & 38 & 32 & - & - \\
\hline Org. Carbon (unfilt.) & 22 & - & - & - \\
\hline Inorg. Carbon (unfilt) & 50 & - & - & - \\
\hline
\end{tabular}


Water samples from all aquifers and from irrigation ditches were tested for the presence of pesticides used for the control of weed and insect growth within the citrus development. The analyses showed no traces of any of these chemicals. Samples will be collected at regular intervals to monitor water quality.

Because the water of the sand aquifer has a low dissolved-solids concentration recharge through the connector well should have a diluting effect upon the water of the Floridan Aquifer, which has a higher dissolvedsolids concentration. The more acidic recharge water could possibly augment solution channel development in the limestone.

\section{PROPOSED CONNECTOR WELL}

\section{$\underline{\text { Recharge Rate }}$}

Methods for estimating the amount of water that could be recharged through connector wells are not highly developed. Two approaches were used in this investigation. In the first, water for recharge is assumed to come solely from storage in the sand aquifer; under these conditions drawdown at the connector we 11 is assumed to be constant and recharge rate declines with time but at a decreasing rate. In the second approach, long-term recharge rate is assumed to equal the rate at which water can be captured from runoff and evapotranspiration; under these conditions, drawdown in the sand aquifer would continue until the recharge rate of the well equals the capture rate and steady tate conditions are reached. In both analyses, transmissivity of the sand aquifer is $1,750 \mathrm{ft}^{2} /$ day $\left(163 \mathrm{~m}^{2} /\right.$ day $)$. Storage coefficient was estimated to be 0.20. Because of the large difference in transmissivity between the sand aquifer and the Floridan Aquifer, build-up of the artesian potentiometric surface was assumed to be negligible, and the available drawdown in the connector we 11 was as sumed to be the full $40 \mathrm{ft}(12.2 \mathrm{~m})$ of initial head difference. In both analyses, adjustments in available drawdown were made to account for dewatering of the upper part of the san. aquifer, based on the method af Jacob (1963). Initial aquifer thickness is $45 \mathrm{ft}(13.7 \mathrm{~m})$, the combined thickness of the two sand units.

Figure 4 shows that the recharge rate analyzed by the constant drawdown method for the conditions stated would be $230 \mathrm{gpm}(14.51 / \mathrm{s})$ after one day and about $155 \mathrm{gpm}(9.8 \mathrm{l} / \mathrm{s})$ after 200 days. The analysis is based on the flowing-we11 equation of Jacob and Lohman (1952), as summarized by Lohman (1972). The method as sumes no water is obtained from capture and that no natural recharge to the sand aquifer occurs. Thus this approach would probably be applicable for the initial operation of the connector well and during dry periods when water would be obtained from storage in the sand aquifer.

As drawdown in the sand aquifer occurs, however, some water that otherwise would have run off or evapotranspired is captured and recharged through the we11. Therefore, use of the capture method probably provides a more reliable indication of the long-term average recharge rate of the connector we 11 . 


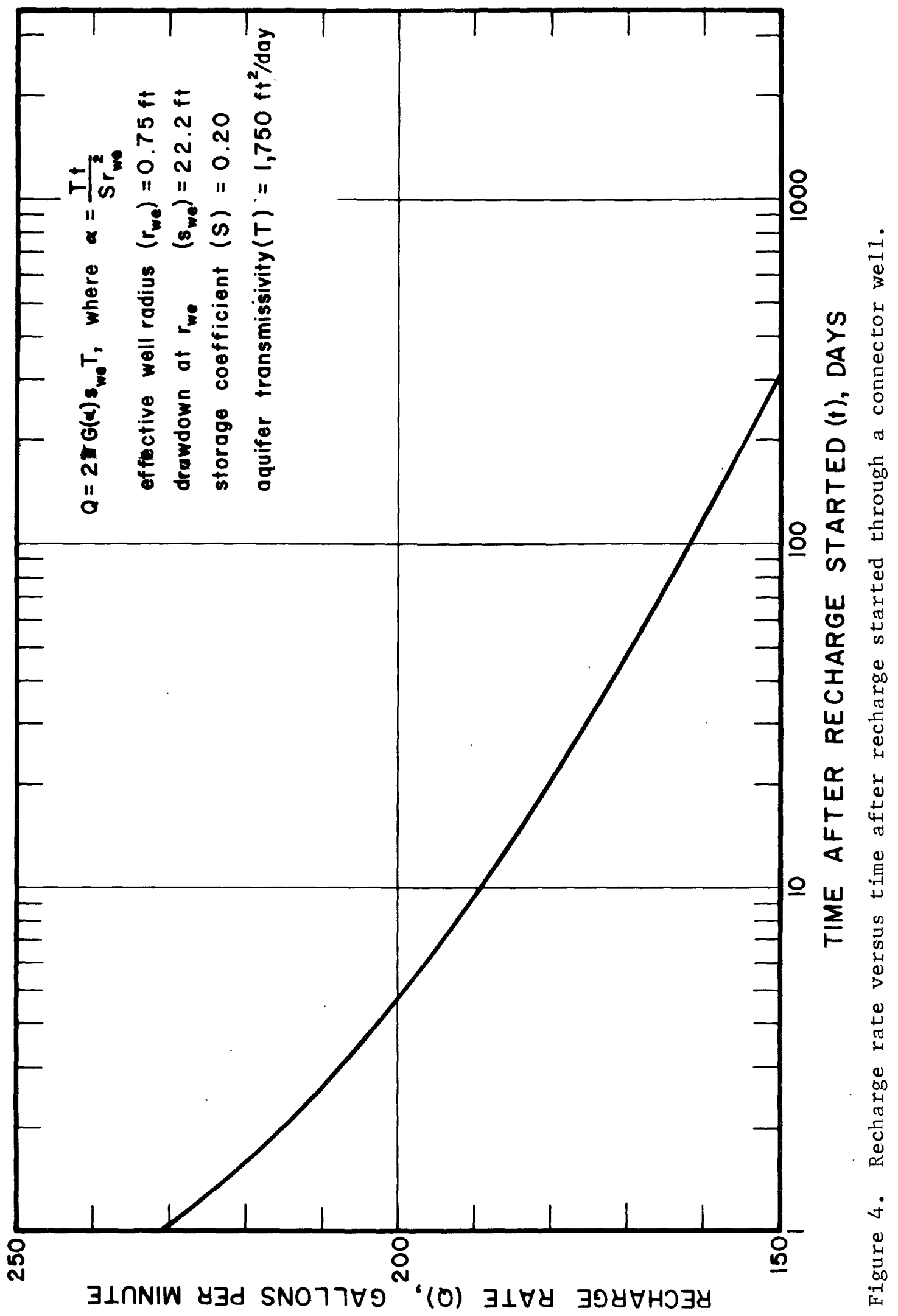


The relations between capture rate and the cone of depression around a connector well are illustrated schematically in figure 5. As described by D. D. Knochenmus (written commun., 1973), for a given set of atmospheric and geologic conditions, capture rate increases with drawdown until at some given drawdown, maximum capture rate occurs. The drawdown associated with the maximum capture rate is the maximum-capture drawdown $\left(\mathrm{s}_{\mathrm{mc}}\right)$, and the radial distance from the we11 to the point of maximum-capture drawdown is the maximum-capture radius $\left(r_{m c}\right)$ of the cone of depression (fig. 5). Thus within the area encompassed bycthis radius, maximum capture rate occurs; beyond this radius, capture rate decreases with decreasing drawdown.

The drawdown around a single connector we11 will increase until enough water is captured to sustain flow at a rate determined by the transmissivity of the water-table aquifer, head difference between the two aquifers, we $11 \mathrm{size,}$ and effectiveness of we11 development. If the maximum capture rate is relatively high, the maximum-capture radius of the cone of depression, and thus the area of maximum capture, will be less than if the maximum capture rate is relatively low (fig. 5). The higher maximum capture rate tends to be offset by the smaller area of maximum capture; as a result, the total amount of water captured, and thus the long-term recharge rate of a single connector well, remains nearly the same regardless of the value of maximum capture rate.

The equations for computing recharge rate of a single connector we11, based on the capture method, are given in appendix 2. The equations were developed by Papadopolus and Cooper (S. S. Papadopolus, written commun., 1973). The computed recharge rates for various we 11 diameters and assumed capture rates show that substantial increases in we 11 diameter and capture rate increase recharge rate by only a few percent (table 5). Recharge rate of a $10-i n .(25-\mathrm{cm})$ we 11 would range only from 154 to $165 \mathrm{gpm}$ ( 9.7 to $10.3 \mathrm{l} / \mathrm{s}$ ) even with a threefold increase in assumed maximum capture rate. In addition the results on table 5 demonstrate that the maximum-capture radius of the cone of depression decreases with increasing maximum can rate, as suggested in figure 5 .

Maximum capture rate is unknown; the values used in the analys is are based on a reasonable range of values, as estimated by D. D. Knochenmus (written commun., 1973). If a network of connector wells were to be instal1ed, determination of the maximum capture rate as well as other factors affecting recharge rate, would be essential for evaluating the most efficient number and spacing of wells. But because recharge rate of a single connector we11 varies little with capture rate, an approximate value is sufficient for purposes of this analysis. Drawdown at maximum capture is also unknown and was assumed to be $5 \mathrm{ft}(1.5 \mathrm{~m})$. With other factors constant, computed recharge rates varied only a few gallons per minute for a range of maximum-capture drawdown values of $0.1 \mathrm{ft}(.03 \mathrm{~m})$ to $10 \mathrm{ft}(3 \mathrm{~m})$.

The recharge rate through a connector well would probably differ from that computed, because field conditions are complex and the efficiency of we11 construction and development is difficult to assess quantitatively. 


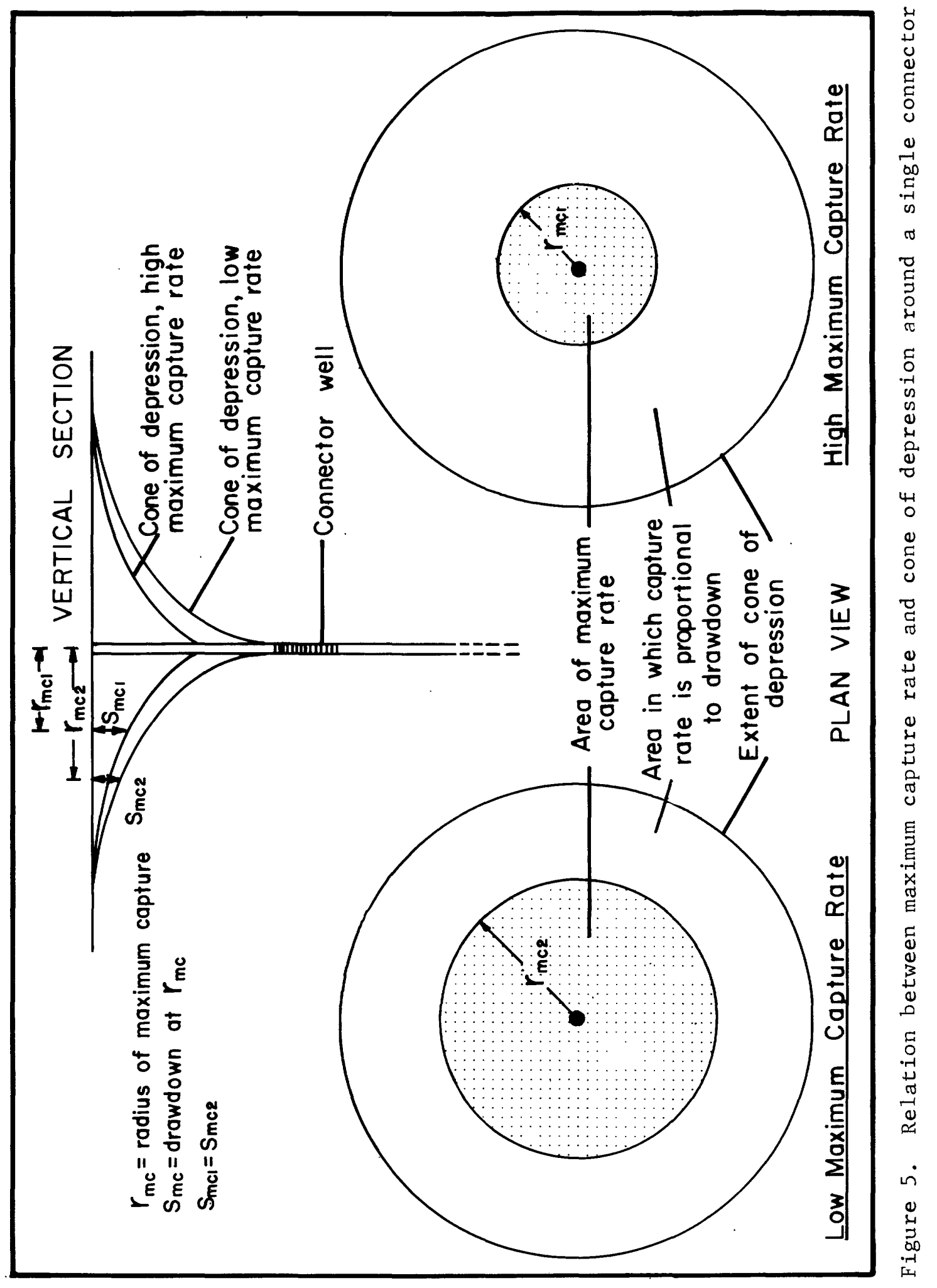


Table 5.--Estimated recharge rate of a test connector we11

\begin{tabular}{|c|c|c|c|c|}
\hline $\begin{array}{l}\text { Maximum } \\
\text { capture } \\
\text { rate } \\
\text { (ft/yr) }\end{array}$ & $\begin{array}{c}\text { Wel1 } \\
\text { diameter } \\
\text { (inches) }\end{array}$ & $\begin{array}{l}\text { 'Effective } \\
\text { well } 1 \\
\text { radius } \\
(\mathrm{ft})\end{array}$ & $\begin{array}{c}\text { Maximum-capture } \\
\text { radius of } \\
\text { cone of } \\
\text { depression } \\
\text { (ft) }\end{array}$ & $\begin{array}{c}\text { Recharge } \\
\text { rate } \\
\text { (gpm) }\end{array}$ \\
\hline 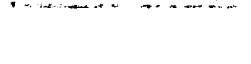 & 10 & 0.75 & 496 & 154 \\
\hline 0.5 & 14 & .92 & 523 & 158 \\
\hline & 22 & 1.25 & 553 & 164 \\
\hline 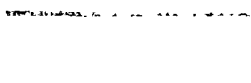 & 10 & $\begin{array}{ll}\cdots \\
\end{array}$ & 322 & 165 \\
\hline 1.5 & 14 & .92 & 341 & 169 \\
\hline & 22 & 1.25 & 364 & 177 \\
\hline
\end{tabular}

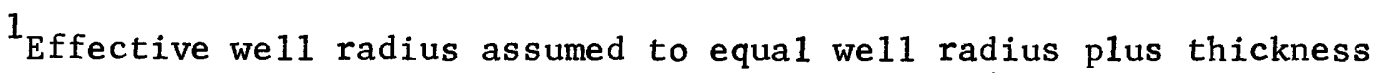
of filter pack. Filter-pack thickness equals $4 \mathrm{in} \cdot(10 \mathrm{~mm})$.

${ }^{2}$ Maximum-capture radius of cone of depression is the distance from the connector well to the point where drawdown of the water table equals that at which maximum capture is obtained; assumed to be $5 \mathrm{ft}(1.5 \mathrm{~m})$ in the analysis. 
In the analysis, the sand aquifer was treated as a single, homogeneous isotropic unit. In fact, however, a $5-\mathrm{ft}(1.5-\mathrm{m})$ clay bed hydraulically separates the upper fine sand unit from the lower coarse sand unit. The two units could be treated as separate aquifers and the yield from each unit computed, but because of the uncertainties in the analytical methods, such a refinement is probably not warranted. The water leve 1 in the we 11 would drop below the upper fine sand unit, and, during the dry season, even below the medium-coarse sand unit (see fig. 3). Thus the water table adjacent to the well face may be lowered below the tops of the screens, thereby reducing well efficiency.

On the other hand, conditions at the site could be altered to increase both the amount of water available for recharge and the ease with which it can move toward the connector we11. These changes, which would result in an increased recharge rate, include installing a system of tiles, flooding the land surface, and perforating the clay layer that separates the sand units.

A radial system of porous tiles installed several feet below land surface, with the connector well at the hub, would facilitate movement of infiltrating surface water or rainwater toward the we11. During dry periods the tiles would have no effect because the water table would drop below them.

Flooding the shallow depression probably offers the most promising technique for substantially increasing the amount of water available for recharge. To be effective, the relatively impermeable peat and muck would have to be removed, thereby exposing the underlying sand. The effectiveness would then depend upon the infiltration rate that could be sustained into the upper fine sand unit. Probably this rate would be sufficient to maintain a saturated condition in the sand aquifer. If so, dewatering would be minimized, exposure of well screens to air would be reduced, and the head driving water into the Floridan Aquifer would be increased.

Perforation of the clay bed that separates the two sand units would increase the hydraulic connection between them. This improvement could be accomplished easily and rapidly by drilling through the bed at many points with a power auger. During previous test drilling, the sand underlying the clay bed was observed to move up into the hollow-stem auger under pressure once the clay bed was fully penetrated. Thus with some additional backfilling, drilling would result in a network of sand-filled holes, thereby increasing the hydraulic connection between the upper and lower sand units. Under these conditions, the sand aquifer would respond more nearly as a single unit; the likelihood of having perched conditions above the clay bed would be reduced; and movement of water into the medium-coarse sand unit underlying the clay would be facilitated. These conditions, too, would result in increased recharge.

The amount of recharge that could be attained by employing these various techniques is unknown, and can best be determined through experiments with the test connector we11. 
Much of the success of a connector-well system depends upon proper installation of the well itself. Proper construction and installation of well screens and sand or gravel filter packs and proper development of the completed well are essential if theoretical well yields are e-ren to be approached. The relation between the pore size of the filter pack and the grain size of the formation sand is the principal factor that letermines the efficiency of a we11. If the wrong grain size is used, fine sand may migrate into the filter pack and reduce the yield of the well or cause $\therefore$ to produce sand.

The proposed construction of the test connector well at the loSoto County grove follows guide lines developed by E. E. Johnson (1966, Chapt.10) and model applications recommended by A. I. Johnson and others (196i). The filter pack and screen criteria are as follows:

$$
\begin{aligned}
& \mathrm{D}_{30} \text { filter pack } \geq 4\left(\mathrm{D}_{30} \text { aquifer }\right), \text { and } 6\left(\mathrm{D}_{30} \text { aquifer }\right) \\
& \mathrm{C}_{\text {filter pack }} \leq 2.5, \\
& \text { Screen opening } \leq \mathrm{D}_{10} \text { filter pack, }
\end{aligned}
$$

where

$$
\begin{aligned}
\mathrm{D}_{10}= & \text { particle diameter retained on a sieve that allows } 10 \text { percent } \\
& \text { by weight to pass } \\
\mathrm{D}_{30}= & \text { particle diameter retained on a sieve that allows } 30 \text { percent } \\
& \text { by weight to pass } \\
\mathrm{D}_{60}= & \text { particle diameter retained on a sieve that allows } 60 \text { percent } \\
& \text { by weight to pass } \\
\mathrm{C}_{\mathrm{u}}= & \text { uniformity coefficient of filter pack, } \mathrm{D}_{60} / \mathrm{D}_{10} .
\end{aligned}
$$

Good well construction and development practices require placement of different filter packs opposite the upper fine grained and the lower coarser grained sand units. The filter packs are sized to the finest material within each unit. Although the permeability of the filter pack is lowered by this approach, migration of fine sand through the pack will be minimal.

Figure 6 shows representative minimum grain-size distribution curves for the upper and lower sand units, and corresponding curves for the proper filter-pack material. Table 6 lists the data used in selecting the we 11 screen and filter pack.

The $D_{30}$ size of the filter pack for each sand unit was determined by multiplying the $\mathrm{D}_{30}$ size of the aquifer sand distributions by a factor of 5. Five was chosen as the factor because the sands are moderately uniform (E. E. Johnson, 1966, p. 199). $\mathrm{D}_{60}$ and $\mathrm{D}_{10}$ points on the filter pack curves were arbitrarily chosen so that the slope between them produced a $C$ of less than 2.5. Once these three points $\left(D_{10}, D_{30}, D_{60}\right)$ were plotted, a representative curve for the filter pack material was fitted to them. 


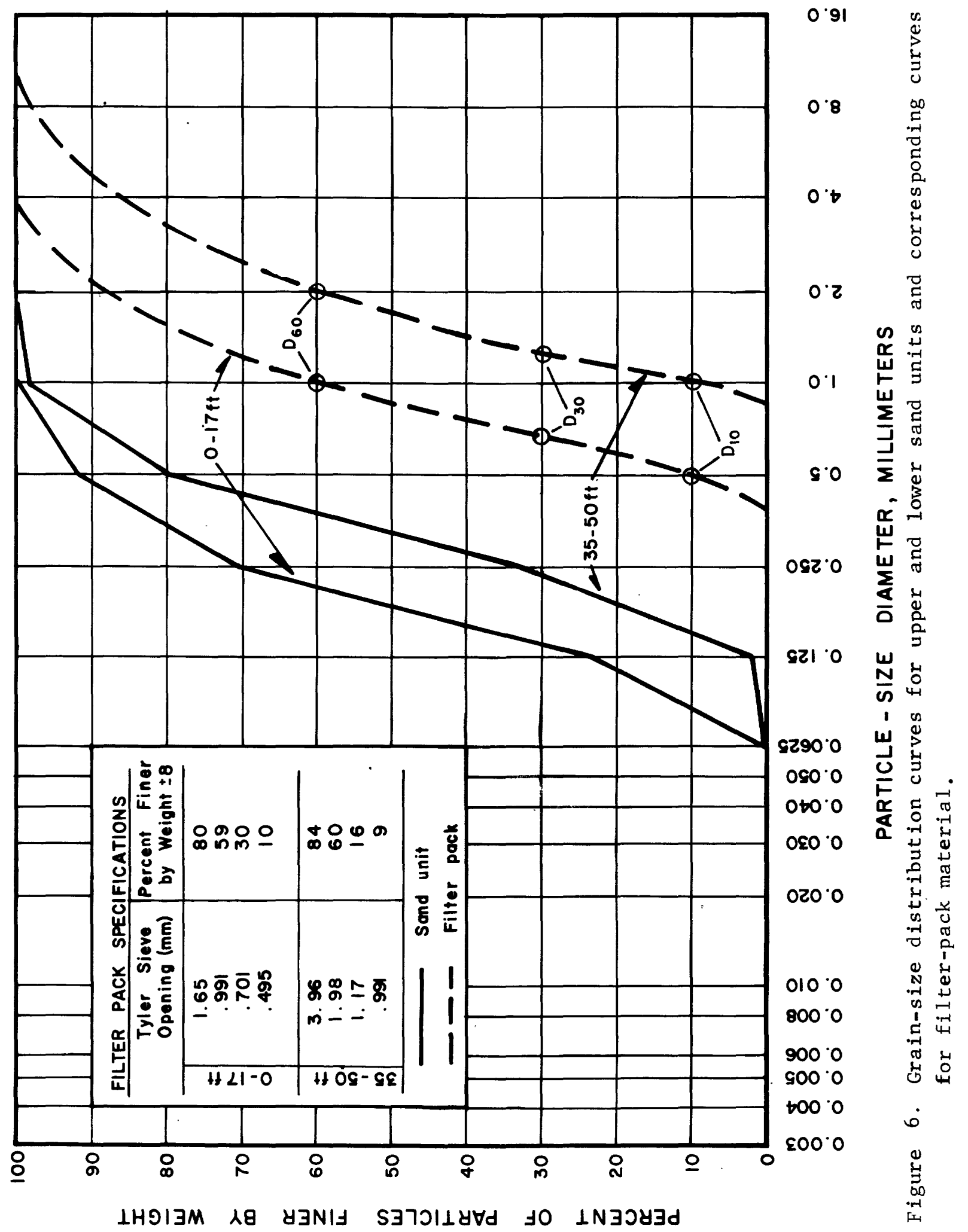


Table 6.--Data for design of test connector-well screen and filter pack

\begin{tabular}{|c|c|c|}
\hline & Upper sand unit & Lower sand unit \\
\hline $\begin{array}{l}\text { Depth interval of unit }(\mathrm{ft}) \\
\mathrm{D}_{30} \text { aquifer }(\mathrm{mm})\end{array}$ & $\begin{array}{l}0-17 \\
0.14\end{array}$ & $\begin{array}{r}35-50 \\
0.24\end{array}$ \\
\hline $\begin{array}{l}\text { Filter Pack: } \\
\mathrm{D}_{30}(\mathrm{~mm}) \\
\mathrm{D}_{10}(\mathrm{~mm}) \\
\mathrm{D}_{60}(\mathrm{~mm}) \\
\mathrm{C}_{60} \\
\text { Thickness (in) }\end{array}$ & $\begin{array}{r}.70 \\
.50 \\
1.00 \\
2.0 \\
4.0 \\
\end{array}$ & $\begin{array}{l}1.20 \\
1.00 \\
2.00 \\
2.0 \\
4.0\end{array}$ \\
\hline $\begin{array}{l}\text { Screen: } \\
\text { Slot size (in) } \\
\text { Length (ft) } \\
\text { Depth interval (ft) } \\
\text { Diameter (in) }\end{array}$ & $\begin{array}{l}.020 \\
6.0 \\
11-17 \\
8\end{array}$ & $\begin{array}{l}.035 \\
12.0 \\
38-50 \\
8\end{array}$ \\
\hline
\end{tabular}


Specifications for grain size of the filter-pack materials given in the inset of figure 6 are determined from their distribution curves. The percent finer by weight values for various Tyler sieve opening sizes are determined from corresponding particle-size diameter values and the filter-pack distribution curves. E. E. Johnson (1966, p. 200) suggests that a reasonable permissible range may be plus or minus 8 percentage points from the determined value. Firms that produce uniformly graded sands have large stocks of these materials and the filter-pack specifications can be met easily. Filter-pack material should be clean with we11-rounded grains so that permeability will be increased and hydraulic separation will be minimal as the particles settle around the screen.

Screen specifications for the connector we11 are determined from analyses of the filter-pack materials and the lithologic logs of the test holes. Screens are designed to be placed opposite the uniform sands of the upper and lower aquifers as shown in figure 7 . Screen slot sizes of 0.020 in. $(0.5 \mathrm{~mm})$ and $0.035 \mathrm{in} .(1.0 \mathrm{~mm})$ were chosen to coincide with the effective sizes $\left(D_{10}\right)$ of the upper and lower filter packs, respectively. E. E. Johnson (1966, p. 188) recommends that it is practical to screen only the bottom 33 percent of a homogeneous unconfined aquifer. In a homogeneous artesian aquifer, such as the lower sand unit, about 80 percent is satisfactory. The screen length should be $6 \mathrm{ft}(1.8 \mathrm{~m})$ in the upper sand unit and $12 \mathrm{ft}(3.6 \mathrm{~m})$ in the lower sand unit. Although dewatering of the lower sand unit may eventual1y cause it to respond as an unconfined aquifer, subsequent flooding experiments should make maximum use of the 80 percent screen length. A screen diameter of $10 \mathrm{in.}(25 \mathrm{~cm})$ was chosen based upon anticipated recharge rates and practical considerations of drilling the we11. A filter-pack thickness of $4 \mathrm{in.}(10 \mathrm{~cm})$ would increase the effective radius of the wel1 to about 9 in. $(23 \mathrm{~cm})$.

Inclusion of an artificial filter pack in the construction of the we 11 probably increases the cost because of additional time and materials required for placement of the filter pack and development of the packed we11. However, use of an artificial filter pack at the proposed connector well site has several advantages over a natural filter pack: (1) it will allow installation of screens with larger openings, which, by permitting ground water to enter the we11 at a lower velocity, will inhibit screen incrustation and reduce we 11 loss; (2) it will allow some vertical drainage, thus facilitating drainage of the upper sand unit; (3) it will allow some latitude in placement of screens opposite the upper and lower sand units, which have gradational stratigraphic contacts; and (4) it will increase the effective radius of the we11, thereby increasing the recharge rate by a sma11 percentage.

As shown in figure 7 , the connector we11 is to be cased opposite the secondary aquifer and the overlying and underlying confining beds, and open hole for about $250 \mathrm{ft}(76 \mathrm{~m})$ in the Floridan Aquifer. The length of the open-hole section would depend upon the permeability of the upper part of the Floridan Aquifer encountered in drilling; the rock well should be capable of yielding (or accepting) several hundred gallons per minute to ensure against mounding after recharge begins. Proper development of the 


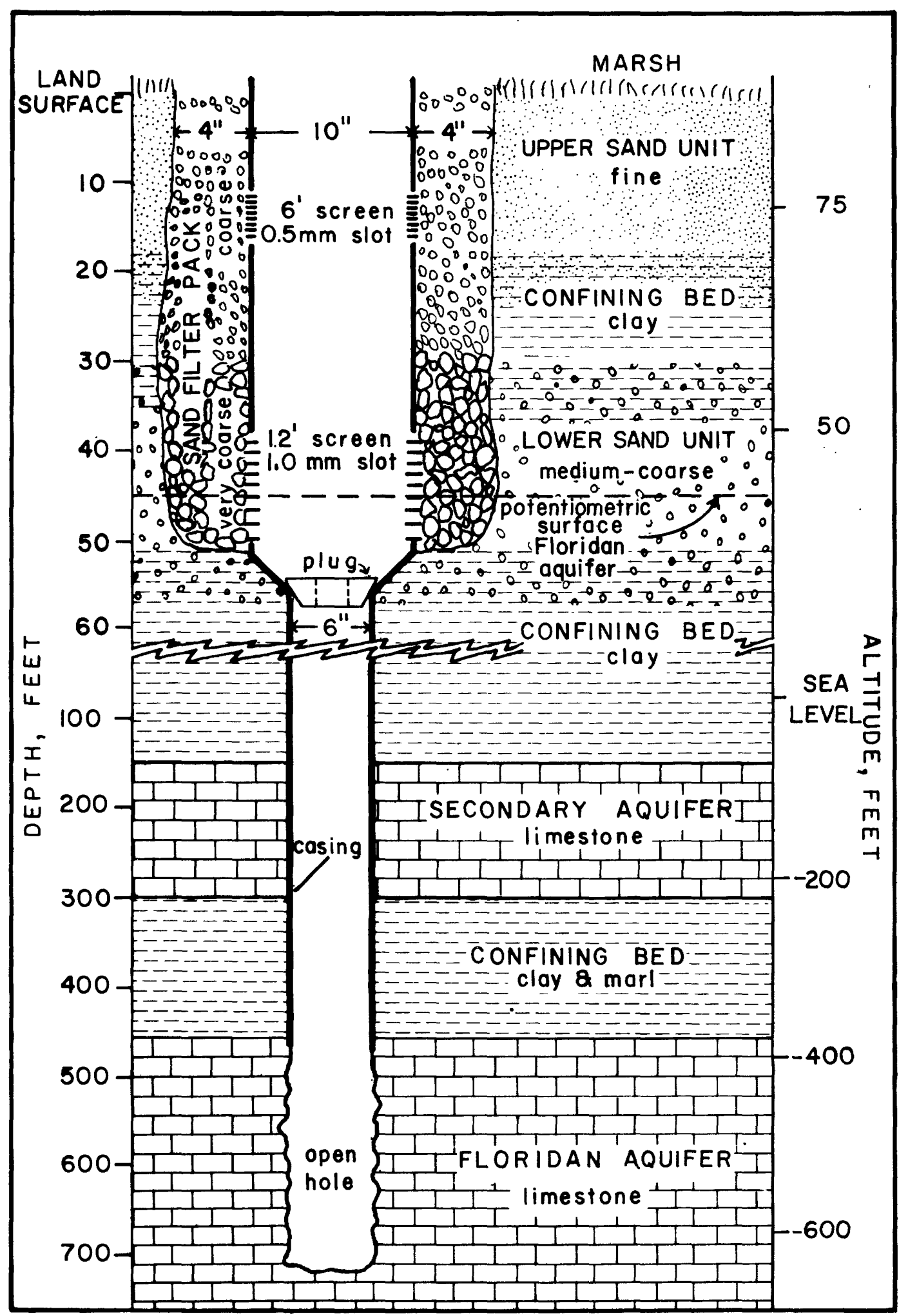

Figure 7. Design of the test connector well and filter pack. 
11 is essential in order to obtain maximum yie1ds. Loss of water circulation can occur if the we11 is open to the highly transmissive limestone Juring development of the screened sections. Thus, effective development c.an be accomplished by installing and developing the $10-$ in. $(25-\mathrm{cm})$ screened parts of the well before drilling the 6-in. (15-cm) lower section.

\section{SUMMARY AND CONCLUSIONS}

The sand aquifer that underlies most marshes i: a large citrus grove in hortheastern DeSoto County consists of about $50 \mathrm{ft}(15 \mathrm{~m})$ of principally fine sand. At one marsh, in the northwestern part of the grove, the section izcludes $15 \mathrm{ft}(4.6 \mathrm{~m})$ of medium-coarse sand, and this area was selected as he most suitable test site for a proposed connector we11. A properly onstructed we11 at this site would theoretically recharge shallow ground iater to the underlying Floridan Aquifer at an initial rate of about 230 $\mathrm{pm}(14.51 / \mathrm{s})$ but declining to an average rate of about $160 \mathrm{gpm}(10.1 \mathrm{l} / \mathrm{s})$

The selected we11 construction incorporates we 11 screens 10 inches $(25.4 \mathrm{~cm})$ in tiameter placed opposite the upper and lower units of the sand aquifer, 6-in. $(15-\mathrm{cm})$ casing through the underlying confining beds and secondary artesian a ruifer, and open hole in Floridan Aquifer. A 4-in. (10-cm) filter pack blaced around the screens would enhance its efficiency for recharge. Water of the sand aquifer has a low dissolved-solids content, and recharging the Floridan Aquifer with this water will dilute the more mineralized water in $\because$ ie deep aquifer. No pesticides were detected in samples of ground and irface water at the grove in 1972. A program of periodic sampling would litect any deterioration of water quality and provide a basis for assessing $\because$ e effects of recharge on ground-water quality. The high iron content of $\because e$ upper sand unit may result in an iron scale build-up if screens are is rated.

We11 yie1ds could probably be increased substantially above computed ralues by installing a subsurface system of tiles, surface flooding, and $\because$ perforating the $5-\mathrm{ft}(1.5 \mathrm{-m})$ clay layer that separates the upper and wer units of the sand aquifer. The effects of these techniques could be sessed quantitatively by proceeding in the following sequence:

1) Dri11 connector we11 and clear the test site of peat and muck.

2) Determine recharge rate.

3) Flood the test site.

4) Determine recharge rate.

5) Drain the test site.

6) Insta11 tile system.

7) Flood the test site.

8) Determine recharge rate.

9) Drain test site.

10) Puncture the $5-\mathrm{ft}(1.5-\mathrm{m})$ clay bed at many points, using a power auger, and backfill the boreholes with coarse sand.

11) Flood the test site.

12) Determine recharge rate. 


\section{REFERENCES}

Jacob, C. E., 1963, Determining the permeability of water-table aquifers, in Bental1, Ray, compiler, Methods of determining permeability, transmissibility, and drawdown: U. S. Geo1. Survey Water-Supply Paper $1536-I$, p. 245-271.

Jacob, C. E., and Lohman, S. W., 1952, Nonsteady flow to a we 11 of constant drawdown in an extensive aquifer: Am. Geophys. Union Trans., v. 33, no. 4, p. 559-569.

Johnson, A. I., Moston, R. P., and Versaw, S. F., 1966, Laboratory study of aquifer properties and we11 design for an artificia1-recharge site:

U. S. Geo1. Survey Water-Supp1y Paper 1615-H, 42 p.

Johnson, E. E., 1966, Ground water and we11s: St. Pau1, Minn., Edward E. Johnson, Inc., 440 p.

Lohman, S. W., 1972, Ground-water hydraulics: U. S. Geo1. Survey Prof. Paper 708, 70 p.

Lohman, S. W., and others, 1972, Definition of selected ground-water terms-revisions and conceptual refinements: U. S. Geo1. Survey Water-Supply Paper 1988, $21 \mathrm{p}$.

Masch, F. D., and Denny, K. J., 1966, Grain-size distribution and its effect on the permeability of unconsolidated sands: Water Resources Research, vo1. 2 , no. 4, p. 665-677.

Pettijohn, F. J., 1957, Sedimentary rocks: New York, Harper and Brothers, $718 \mathrm{p}$.

Puri, H. J., and Vernon, R. O., 1964, Summary of the geology of Florida and guidebook to the classic exposures: Florida Geo1. Survey Special Pub. No. $5,312 \mathrm{p}$.

Wilson, W. E., 1972, Hydrogeology of Florida's largest citrus grove, in Age of changing priorities for land and water: Proc. Irrig. and Drainage Specialty Conf. Amer. Soc. Civil Engineers, Spokane, Washington, 1972, p. 293-307. 


\section{APPENDIXES}

Appendix 1. Lithologic logs of we11 and test-hole sites

Locations of we 11 and test-hole sites at the grove are shown in $f$ igure 2. Log headings show: (1) test-hole or we11-set number; (2) location, based on coordinates of 1-minute parallels of latitude and 1-minute meridians of longitude; (3) section, township, and range; and (4) altitude of land surface, either surveyed or taken from $7 \frac{1}{2}-$ minute topographic maps with 5-foot contour intervals. Each observation we11 is constructed of plastic pipe 2 in. $(5 \mathrm{~cm})$ in diameter, and is finished with a $1.5-\mathrm{ft}(0.5-\mathrm{m})$ steel screen, 1.25 in. $(3.18 \mathrm{~cm})$ in diameter and 60 mesh.

Grain-size classification is based on the Wentworth scale. Color description is from field comparison of samples with the standard Geologic Society of America rock-color chart. 
2S $271732 \mathrm{~N} 0814030.1$

2D 271732N0814030.2

$\mathrm{NW} \frac{1}{4} 1-37 \mathrm{~S}-26 \mathrm{E}$
Altitude of land surface, 89.0 feet Wel1 depths:

$2 \mathrm{~S}=22.5$ feet

$2 \mathrm{D}=46.0$ feet

Depth below land surface (feet) Lithology

$0-0.5$

$0.5-5$

$5-13$

$13-26$

$26-31$

$31-38$

$38-54$

$54-65$

65-75

75-84
Peat

Sand, fine, moderate-brown

Sand, fine, 1ight-olive-gray

Sand, medium to coarse, clayey, some phosphate grains and shell fragments, 1ight-olive-gray.

Clay, stiff, greenish-gray

Sand,coarse, clay matrix, some phosphate grains, greenish-gray

Sand, coarse, well sorted, greenish-gray

Sand, fine to medium, clay matrix, olive-gray

Sand; fine, clayey, dark-greenish-gray

Sand,medium, stiff clay matrix, dark-greenish-gray 
We11 Set 3

3S $\quad 271729 \mathrm{~N} 0814030.2$

3D $271729 \mathrm{~N} 0814030.1$

NW $\frac{1}{4}$ 1-37S-26E

Altitude of land surface, 87.7 feet We11 depths:

$3 \mathrm{~S}=11$ feet

$3 \mathrm{D}=42$ feet

Depth below

land surface (feet)

Lithology

$0-2$

Peat

$2-16$

Sand, fine, moderate-to pale-brown

$16-26$

Sand, medium to coarse, clayey, some phosphate grains and she11 fragments, 1ight-olje-gray

$26-31$

Clay, stiff, greenish-gray

$31-37$

Sand, medium to coarse, clay matrix, some phosphate grains, greenish-gray

$37-43$

Sand, coarse, well sorted, greenish-gray 
Well Set 4

4S $271728 \mathrm{~N} 0814030.3$

4D 271728N0814030.2

4 271728N0814030.1

$\mathrm{NW} \frac{1}{4}$ 1-37S-26E
Altitude of 1 and surface, 87.7 feet Well depths:

$4 \mathrm{~S}=11$ feet

$4 \mathrm{D}=38$ feet

$4=65$ feet

Depth below Lithology

land surface (feet)

$0-2.5$

$2.5-17$

$17-25$

25-31

$31-35$

$35-45$

45-52

$52-65$
Peat

Sand, fine, pale-brown

Sand, medium to coarse, clayey, some phosphate grains and shell fragments, light-olive-gray

Clay, stiff, some shel1 fragments, light-greenish-gray

Sand, medium to coarse, clay matrix, some phosphate grains, greenish-gray

Sand, coarse, well-sorted, greenish-gray

Sand, medium to coarse, light-olive-gray

Sand, medium to coarse, clayey, dark-greenish-gray 


\section{We11 Set 5}

5S $271728 \mathrm{~N} 0814030.5$

5D 271728N0814030.4

NW $\frac{1}{4} \quad 1-37 S-26 E$
Altitude of land surface, 87.7 feet Well depths: $5 \mathrm{~S}=11$ feet $5 D=38$ feet

Depth below

$0-3$

$3-17$

$17-25$

$25-30$

$30-35$

$35-38$
Peat

Sand, fine, pale-brown

Sand, medium to coarse, clayey, some phosphate

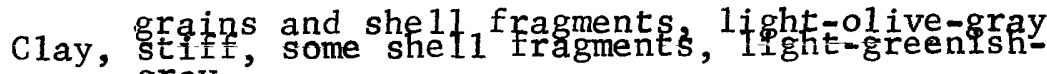
gray

Sand, medium to coarse, clay matrix, some phosphate grains, greenish-gray

Sand, coarse, well-sorted, greenish-gray 
Test hole 5

271336N0814000

Altitude of 1 and surface, $80 \pm$ feet

$\mathrm{SE} \frac{1}{4} 25-37 \mathrm{~S}-26 \mathrm{E}$

Depth below

1and surface (feet)

Lithology

$0-3$

3-6

$6-10$

$10-15$

$15-20$

20-25

$25-32$

$32-42$

$42-49$

Sand, fine, road fill

Peat, sandy

Sand, fine to medium, dark-yellowish-brown

Sand, medium to coarse, dark-yellowish-brown

Sand, fine to medium, dark-yellowish-brown

Sand, medium to coarse, dark-yellowish-brown

Sand, medium to coarse, clayey, dark-yellowish-brown

Sand, coarse, clayey, dark-greenish-gray

Clay, stiff, dark-greenish-gray 
Test hole 6

$271334 \mathrm{~N} 0813957$

Altitude of land surface, $80 \pm$ feet

$S E \frac{1}{4} \quad 25-37 S-26 E$

Depth below

1and surface (feet)

Lithology

$0-3$

$3-4$

4-15

$15-20$

$20-25$

$25-30$

$30-35$

$35-40$

40-51.5

Sand, fine, fill

Peat, sandy

Sand, fine, organic matter, black

Sand, medium to coarse, dark-yellowish-brown

Sand, very fine to fine, dark-yellowish-brown

Sand, coarse to very coarse, phosphate grains, darkyellowish-brown

Sand, coarse to very coarse, clayey, phosphate grains, dark-yellowish-brown

Sand, very fine, clayey, dark-greenish-gray

clay, silty, with fine sand laminae, dark-greenishgray 
Test hole 7

$271337 \mathrm{~N} 0813807$

$\mathrm{SE} \frac{1}{4}$ 29-37S-27E

Altitude of 1 and surface $84 \pm$ feet

Depth below

1 and surface (feet)

Lithology

0-3

$3-14$

$14-17$

$17-21$

21-23

23-40

40-46

46-56
Sand, fine; road fill

Sand, fine, dusky brown

clay, interbedded sand lenses, dark-greenish-gray

Sand, very fine to fine, dark-yellowish-brown

Sand, medium to coarse, dark-yellowish-brown

Sand, medium to coarse, clayey, phosphate grains, olive-gray

Clay, sandy, phosphate grains, 1ight-olive-gray

Clay, sandy, dark-greenish-gray 
Test hole 8

$271324 \mathrm{~N} 0813758$

Altitude of 1 and surface, $82 \pm$ feet

$\mathrm{SE}_{\mathrm{E}} \frac{1}{4} 29-37 \mathrm{~S}-27 \mathrm{E}$

Depth below

land surface (feet)

Lithology

$0-14$

4-14

Sand, fine; road fill

$14-40$

Sand, fine to medium, dark-yellowish-brown

Sand, coarse, clayey, some phosphate grains and shell fragments, light-olive-gray

$40-49$

clay, sandy, plastic, greenish-gray 
$0-4$

4-15

$15-25$

$25-29$

$29-33$

$33-40$

40-50

$50-58$
Sand, fine; fill

Sand, very fine to fine, dusky-ye11owish-brown

Sand, medium to coarse, pale-yellowish -brown

Sand, coarse to very coarse, clayey, phosphate grains, pale -yellowish-brown

Clay, sandy, green

Sand, coarse, clayey, phosphate grains, greenish-gray

Sand, fine, clayey, greenish-gray

Clay, sandy, dark-greenish-gray 
271420N0813547

$\mathrm{SE} \frac{1}{4} \quad 22-37 \mathrm{~S}-27 \mathrm{E}$
Altitude of land surface, $87 \pm$ feet

\section{Depth below \\ land surface (feet)}

$0-4$

4-8

$8-15$

15-31

31-38

$38-43$

43-54
Sand, fine, some peat; road fill

Peat, sandy

Sand, fine to medium, pale-brown

Sand, fine, dark -yellowish -brown

Clay, stiff, dark-yellowish-brown

Sand, coarse clayey, grayish-black

Clay, sandy, some shell fragments, greenish-gray 
$0-4$

$4=10$

$10-23$

23-24

$24-31$

$31-40$

40-50

50-59
Sand, fine, light brown, road fill

Sand, very fine to fine, light-brown

Sand, fine, dark-yellowish-brown

Clay, sandy, dusky-brown

Sand, fine to medium with clay lenses, moderateyellowish-brown

Sand, medium to very coarse, clayey, phosphate grains and shell fragments, olive-gray

Sand, as above but greater percent clay

Clay, sandy, dark-greenish-gray 
Appendix 2. Equations for computing recharge rate of single connector we11.

The following equations were derived by Papadopulos and Cooper (S. S. Papadopulos, written communication, 1.973) to describe drawdown in the vicinity of a wel1 that derives its discharge from capture of evapotranspiration and/or increased infiltration. For the derivation, it was assumed that the aquifer is homogeneous, isotropic, and infinite in extent; that steady-state conditions prevail (that is, drawdown in the we 11 and the aquifer is constant and well discharge equals capture); that the rate of capture varies linearly with drawdown in areas where drawdown is less than a certain magnitude, $s_{m}$; and that the capture rate is at a constant maximum rate where drawdown is equal to or greater than $\mathrm{s}_{\mathrm{mc}}$. In addition, it is assumed that the maximum drawdown is a small fraction of the aquifer thickness. Under these conditions, the equations for drawdown and discharge are:

$$
\begin{aligned}
& \frac{s_{w e}}{s_{m c}}=1+\ln \frac{r_{m c}}{r_{w e}}\left\{\frac{a^{2} r_{m c}^{2}}{2}+\beta \frac{K_{1}(\beta)}{K_{o}(\beta)}\right\}- \\
& \frac{a^{2} r_{m c}^{2}}{4}\left(1-\frac{r_{w e}^{2}}{r_{m c}^{2}}\right)
\end{aligned}
$$

and

$$
\mathrm{Q}=\pi \mathrm{r}_{\mathrm{mc}}^{2} \mathrm{C}_{\mathrm{o}}+2 \pi \mathrm{T} \mathrm{s}_{\mathrm{mc}} \boldsymbol{\beta} \frac{\mathrm{K}_{1}(\beta)}{\mathrm{K}_{\mathrm{o}}(\boldsymbol{\beta})}
$$

where

$\mathrm{C}_{\mathrm{O}} \quad=$ maximum capture rate, in $\mathrm{ft} / \mathrm{day}$

$\mathrm{K}_{\mathrm{O}}(\beta)=$ zero-order modified Bessel function of the second kind;

$\mathrm{K}_{1}(\boldsymbol{\beta})=$ first-order modified Bessel function of the second kind;

$\mathrm{b}=$ thickness of aquifer, in $\mathrm{ft}$;

$\mathrm{Q} \quad=$ recharge rate, in $\mathrm{ft}^{3} /$ day; $r_{\mathrm{mc}} \quad$ radial distance to the point where drawdown equals $\mathrm{s}_{\mathrm{mc}}$,
in $\mathrm{ft} ;$

$\mathrm{r}_{\text {we }} \quad=$ effective wel1 radius, in $\mathrm{ft}$;

$\mathrm{s}_{\mathrm{mc}} \quad=$ drawdown at which $\mathrm{C}_{\mathrm{o}}$ reaches its maximum, in $\mathrm{ft}$;

$s_{\text {we }} \quad=$ drawdown at $r_{w e}$, in $f t$; 


$$
\begin{aligned}
\mathrm{T} & =\text { transmissivity of aquifer, in } \mathrm{ft}^{2} / \mathrm{day} ; \\
a & =\sqrt{\frac{\mathrm{C}}{\mathrm{T} \mathrm{s}_{\mathrm{mc}}}} ; \\
\beta & =a \mathrm{r}_{\mathrm{mc}}
\end{aligned}
$$

The first equation on the previous page may be solved for $r_{m c}$ by preparing a plot of $s_{w e} / s_{m c}$ versus $r_{m c}$ for the assumed or known values of $\mathrm{C}_{\mathrm{o}}, \mathrm{r}_{\text {we}}$, and $\mathrm{T}$. This graph may be entered at the known or estimated value of $s_{w e} / s_{m c}$ to determine $r_{m c}$. With the value of $r_{m c}$ determined, the discharge $Q$ may be computed from the second equation.

The assumption that drawdown is small relative to aquifer thickness is not always well met for connector wells, and can be avoided by replacing $s_{\text {we }}$ and $s_{m c}$ by $s^{\prime}{ }_{\text {we }}$ and $s^{\prime}{ }_{m c}$, where $\quad s^{\prime}{ }_{\text {we }}=s_{\text {we }}-s_{\text {we }}^{2}$ and $s^{\prime}{ }_{m c}=s_{m c}-$ $\mathrm{s}_{\mathrm{mc}}^{2}$. Under these conditions, however, it must be assumed that the capture $\overline{2 \mathrm{~b}}$ ise is linearly related to $s^{\prime}$, rather than $s$, where $s^{\prime}=s-\frac{s^{2}}{2 b}$, for values of $s^{\prime}$ less than $s^{\prime}{ }^{\prime} c^{\cdot}$

The equations thus become:

$$
\begin{aligned}
& \frac{s^{\prime}{ }_{w e}}{s^{\prime}{ }_{m c}}=1+1 n \frac{r_{m c}}{r_{w e}}\left\{\frac{a^{\prime 2} r_{m c}^{2}}{2}+\beta^{\prime} \frac{K_{1}\left(\beta^{\prime}\right)}{\mathrm{K}_{\mathrm{o}}\left(\beta^{\prime}\right)}\right\}- \\
& \frac{{a^{\prime}}^{2}{ }_{r_{m c}}^{2}}{4}\left(1-\frac{r_{w e}^{2}}{r_{m c}^{2}}\right)
\end{aligned}
$$

and $\mathrm{Q}=\pi \mathrm{r}_{\mathrm{mc}}{ }^{2} \mathrm{C}_{\mathrm{o}}+2 \pi \mathrm{T} \quad \mathrm{s}_{\mathrm{mc}}^{\prime} \beta^{\prime} \frac{\mathrm{K}_{1}\left(\beta^{\prime}\right)}{\mathrm{K}_{\mathrm{o}}\left(\beta^{\prime}\right)}$

where $\boldsymbol{a}^{\prime}=\sqrt{\frac{\mathrm{C}_{\mathrm{o}}}{\mathrm{Ts}_{\mathrm{mc}}}}$;

$$
\beta^{\prime}=\alpha^{\prime} r_{\mathrm{mc}} ;
$$

and other values are as previously described.

These equations may be solved for the radius of maximum capture, ${ }{ }_{m c}$ ' and discharge, $Q$, in the same manner as described above. 


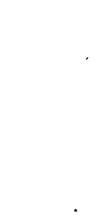




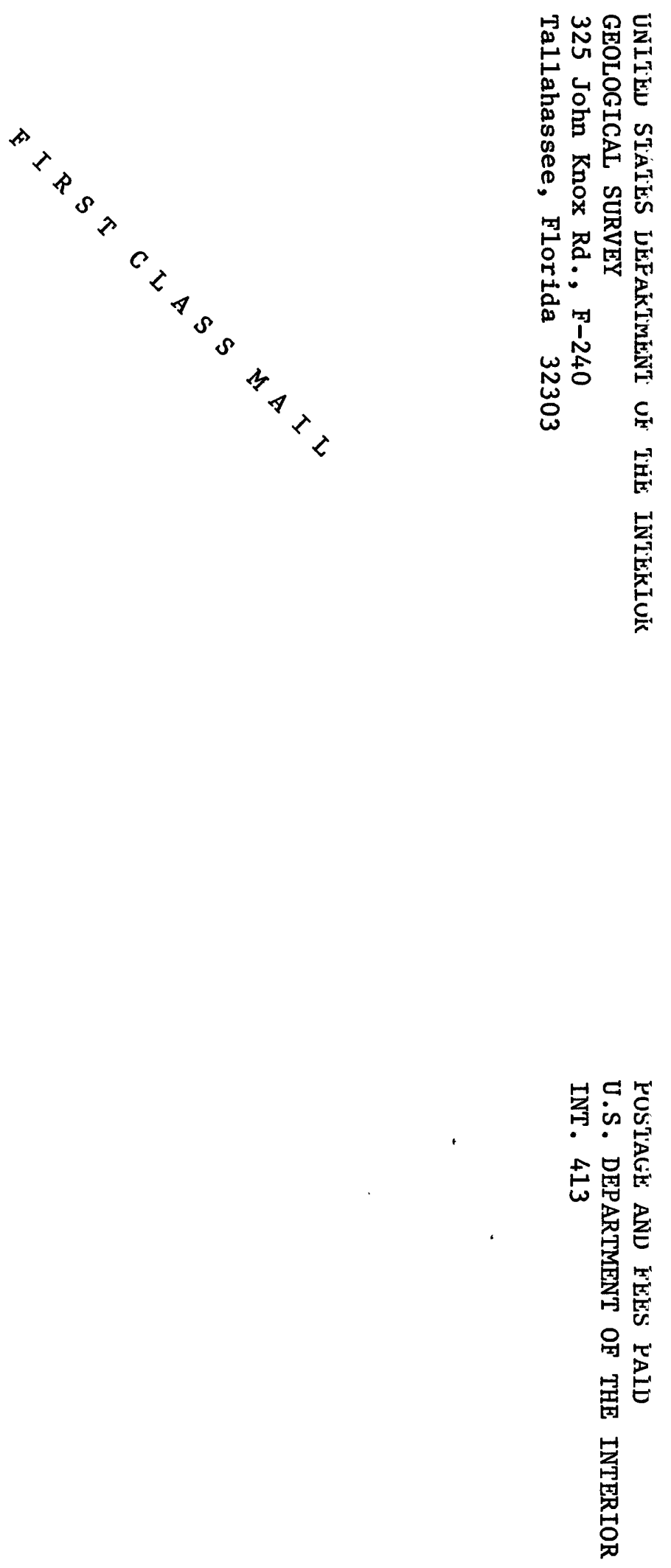